\title{
"The European Lavender Vote: Sexuality, Ideology and Vote Choice in Western Europe."
}

\author{
Stuart J. Turnbull-Dugarte* \\ Department of Political Economy \\ King's College London \\ This is a pre-accepted manuscript. \\ Please use the correct citation at the European Journal of Political Research
}

In many European democracies, political punditry has highlighted the attempts of political parties on the left to court the "lavender vote" of lesbian, gay and bisexual individuals. This article examines the presence of a gay vote in Western Europe with a focus on assessing the role of sexuality in shaping individuals' political preferences and voting behaviour. Empirically, the effect of sexuality on both ideological identification as well as party vote choice is analysed. Using a cumulative dataset of eight rounds of the European Social Survey between 2002-2017, this article demonstrates that partnered lesbians and gay men are more likely than comparable heterosexuals to identify with the left, support leftist policy objectives, and vote for left-of-centre political parties. The analysis represents the first empirical crossnational European study of the voting behaviour of homosexual individuals and sheds new light on the importance of sexuality as a predictor of political ideology and voting behaviour within the Western European context.

*stuart.turnbull_dugarte@kcl.ac.uk

I thank Sarah Birch, Pablo Simón, Damien Bol, Joshua Townsley and Sawyer Phinney for their detailed comments and helpful advice on earlier iteration of this paper. 


\section{INTRODUCTION}

The study of gay politics has recently established an observable voice in political science. Gay politics, questions of political science of interest to and motivated by individuals who are lesbian, gay or bisexual (LGB) $)^{\mathrm{i}}$, has entered the literature in the form of legislative (Cohan, 1982; Kollman, 2017; Reynolds, 2013) and judicial (Anderson, 2006; Klarman, 2012) decision-making studies; public policy analysis (Lewis \& Oh, 2008; Portelli, 2004; Silberman, 2006); investigations tracing public opinion and electoral competition (Abou-Chadi \& Finnigan, 2018; Adam, 2003; Haider-Markel, 2010; Magni \& Reynolds, 2018) and research focusing on the impact of social and political movements (Ayoub \& Paternotte, 2014; Bullert, 1987; Kollman \& Paternotte 2013; Mucciaroni, 2008). Despite some notable exceptions (Bailey, 1999; Edelman, 1993; Egan, 2012; Hertzog, 1996; Schaffner \& Senic, 2006), the role of homosexuality in explaining individual-level electoral behaviour remains quite underassessed. This deficit is even more apparent outside of the US context.

What is known regarding the individual-level behaviour of homosexual individuals has evolved out of Hertzog's seminal work The Lavender Vote (1996). The LGB minority in the US consistently expresses a more liberal ideological preference, identifies more with the Democrats and subsequently tends to vote for Democratic candidates as opposed to the Republicans. We do not know, however, whether the explanatory power of sexuality extends to the Western European context. I offer the first empirical assessment of LGB electoral behaviour across Western Europe.

The study of sexuality and its effects on political behaviour is complex both theoretically (Cass, 1979; Cook, 1999; Kinsey, Pomeroy \& Martin, 1948) and methodologically (Black et al., 2000; 
Harry, 1986; Martin \& Dean, 1993; Martin \& Knox, 2000; McClennen, 2003; Sullivan \& Losberg, 2003). Theoretically, it is difficult to conceptualise what homosexuality is and who homosexuals are ${ }^{\mathrm{ii}}$. Methodologically, homosexuality is hard to observe, and this is the difficulty that has most-likely hindered the advancement of further work seeking to assess the effect of being LGB on different political variables. Whilst LGBs have become more visible within the public sphere, including within the political arena (Haider-Markel, 2010; Magni \& Reynolds, 2018), their identification and visibility within the general electorate is still limited. Generally, LGBs look like non-LGBs, so identifying them requires these same LGB individuals to declare themselves as such: homosexuals are a selectively visible social group who elect when to unmask their sexuality which limits the ability of social scientists to study their attitudes and behaviours.

The American National Election Study (ANES), the most comprehensive and widely representative electoral study in the US, has included a direct question regarding respondents' sexual orientation since the late nineties. No domestic or cross-national electoral survey applying random sampling in any EU member state includes a question on sexual orientation however; greatly limiting an assessment of sexuality's shaping effect on voters' ideology or voting behaviour in Europe. This article uses data on the constitution of individual households from eight rounds of the European Social Survey (ESS) across twelve countries in Western Europe to identify LGB individuals and explore the effect of sexuality on individuals' i) ideological identification on the left-right axis, and ii) vote choice. I argue that the "sexuality gap" theorised by Hertzog and empirically observed in the US is transferable to the Western European context. I demonstrate that being LGB in Europe does have an effect on both outcome variables, with homosexuals displaying an increased likelihood of identifying on the left and of voting for left-of-centre political parties. The effect of sexuality is comparable to 
traditional factors associated with ideology and vote choice, such as considerations of social class, cultural identity and valence politics.

This article continues as follows. Firstly, building on the US-based literature, I develop a theoretical explanation of why LGB voters in Europe are likely to behave electorally in a way that is distinct from their heterosexual peers and present the two main hypotheses regarding ideological identification and vote choice. Following this, I provide a description of the data and the operationalisation of the core variables incorporated in the statistical models and detail the adopted method for identifying LGB individuals. Subsequently, I discuss the estimation techniques applied and the results of the same, carrying out a number of robustness checks to ensure the validity of the main findings before providing concluding remarks.

The arguments presented in this paper make a number of contributions. Firstly, it aids the growing literature focusing on gay politics, providing the first individual-level gay vote analysis in a European context and empirically establishes the formation of a lavender vote in Western Europe. Secondly, it deepens the understanding of the determinants of electoral behaviour in Europe. The implications of the analysis suggest that scholars of European electoral politics would do well to include sexuality in their voting models as the results presented in the current analysis suggest that sexuality exhibits an effect on ideological preferences and vote choice that has substantive parity with some of the canonical explanatory factors.

THE EUROPEAN LAVENDER VOTE: EXPLAINING THE SEXUALITY GAP 
The most comprehensive attempt at assessing the voting behaviour of LGB individuals was Hertzog's The Lavender Vote (1996). Hertzog relies predominantly on very localised polling data to demonstrate that LGB individuals i) tend to vote for Democratic candidates, ii) are more likely to identify as liberal, and iii) are more likely to support core leftist policy positions related to welfare and immigration. Hertzog empirically establishes a "sexuality gap" in political preferences and electoral behaviour that cannot be explained by a host of confounding socioeconomic variables. The Lavender Vote laid the groundwork for future research assessing the voting behaviour of LGBs in future electoral contests in the US and its findings have found repeated empirical confirmation across successive elections at the local (Bailey, 1999) and presidential (Lewis, Rogers \& Sherrill, 2011; McThomas \& Buchanan, 2012) levels even when catering to the potential self-selection effects attributable to adopting the LGB identity (Egan, 2012).

Two theoretical arguments explain the sexuality gap in the political preferences between LGB and non-LGB individuals. Firstly, the experience of growing up as LGB will engender a shift in political inclinations as a result of the marginalisation and shared experience of institutional discrimination that LGBs are exposed to (Hertzog, 1996). This argument relies on the work of Campbell et al. (1960), who argue that social forces and personal experiences can alter individuals' political views against what might more commonly be predicted by their upbringing and socio-economic status. Social and institutional discrimination (Bronski, 2011; Faderman, 2016) make homosexuals acutely aware of the hardship experienced by those "othered" by the establishment, which drives them to identify more with ideals that promote political solidarity, egalitarianism and "fairness" (Hertzog, 1996). This, by extension, makes homosexual voters ideal coalition partners for both ethnic minorities and the poor and working classes (Bailey, 1999). Egan (2012: 614) demonstrates that LGB and non-LGB political 
predispositions diverge even before opportunities for political or partisan mobilisation can take place and shows that LGBs are, "from the moment they come of age, from the moment they begin participating in electoral politics and regardless of where they live", more likely to be on the left, meaning that the LGB experience influences the development of political predispositions (Bailey, 1999) that cannot be explained by their geographic or socio-economic circumstances.

Secondly, as a distinct social group with their own group-specific policy objectives sexual minorities will align themselves politically and express their vote choice as a means of maximising their shared policy benefits. In the case of LGB voters, the policy demands likely to fall at the heart of their LGB status are civil rights protection laws and anti-discrimination measures. The pursuit of these demands is aggregated via the group's shared identity (Hertzog, 1996) and common grievances (Sherrill, 1996) leading to political activism and the emergence of gay rights movements - often concerted in urban settings where gay populations are geographically concentrated (Bailey, 1999) - that seek to mobilise policy-makers and political parties to fulfil the supply-side of their demands. In the US context the rising significance of the gay rights movement and their demands to legislators has launched gay rights issues into the mainstream political debate. Democratic candidates' promotion of pro-gay stances in the face of Republican opposition over gay rights issues (Adam, 2003; Rimmerman, 1996; Button, Rienzo and Wald, 1996) itself shows that policy-makers are seeking to satisfy the electoral demand for these policies, and we can assume that mobilisation effects are taking place on the voters who would seek to benefit from these policies as has been the case with group-orientated voting (Huddy, 2013) based on race in the US (Campbell et al., 1960; Verba and Nie, 1972) and, historically, with class-based mobilisation amongst workers and employers in Europe (Lipset and Rokkan, 1967). Indeed, as Egan (2012: 612) argues in the case of homosexual 
voters in the US, the updating of partisan preferences from gay individuals whose background would suggest a political identification with the right who shift their preferences towards the left is likely motivated by mobilisation of the group identity responding to parties' positions on gay rights issues.

LGBs in Europe have also been subjected to discriminatory policies imposed upon them by the heterosexual majority and we can expect a similar alteration in political orientations to occur as a result of the LGB experience. Homosexuals represent a marginalised and discriminated social group within Western European society (Adam, Duyvendak and Krouwel, 1999; Altman, 2012; Martels, 2000; Trappolin, Gaspirini, and Wintemute, 2012) $)^{\mathrm{iii}}$. Taking the UK as an illustrative example, homosexual acts between consenting males were not legalised in the whole of the UK until 1981, and gay males were prohibited from engaging in sexual activity in hotels until 2001. It was also not until 2001 that the age of sexual consent between two men was lowered to gain parity with that of opposite-sex couples. Homosexuals were also prohibited from enlisting in the UK military until 2000, and state schools were prohibited from discussing homosexuality in a positive way, deemed under Section 28 as promoting homosexuality, until the removal of Section 28 from that statute books in 2003 (Sommerlad, 2018). Employers could legally dismiss employees because of their sexual orientation until 2003 and the UK did not recognize same-sex domestic partnerships until 2004 preventing same-sex partners from qualifying for the fiscal benefits that being in a legally-recognised relationship would provide.

Processes of social, economic and cultural ostracization and, at times, violence also victimize LGB individuals. The number hate crimes against gay people is on the rise (Bulman, 2017) despite evidence of underreporting of the same (Government Equalities Office, 2018) and gay 
people also suffer from a higher probability of experiencing mental illnesses such as depression and suicide rates are higher vis-à-vis heterosexuals (Government Equalities Office, 2018). Homosexual males in Europe also earn less than comparable heterosexual males (Ahmed and Hammerstedt, 2010). Similar patterns of institutional and personal discrimination exist across much of Western Europe (Adam, Duyvendak \& Krouwel, 1999; Martels, 2000; Tappolin, Gasparini \& Wintemute, 2012). These experiences may engender a certain set of ideological preferences that would likely not have occurred had they been heterosexual. As observed in the US case, we might then expect these ideological preferences to reflect support for political policies focused on empowering those most socially and politically disadvantaged in society, making European homosexuals the ideal coalition partners of left-leaning political parties whose core voter pool has historically centred on the disadvantaged and working classes (Lipset \& Rokkan, 1967). Moreover, the natural political coalitions between LGB and nonLGB interest groups on the left such as those of the poor and working class observed in the states (Bailey, 1999) have also been observed in Europe (for example: the Lesbians and Gays Support the Miners movement during the 1984-85 miner's strike in the UK). Since the experiences of being gay may radicalise homosexuals to make them more supportive of leftist ideals based on improving socio-economic conditions (Bailey, 1999; Hertzog, 1996; Schaffner \& Senic, 2006) this may also contribute to support for leftist political parties.

In addition, political party mobilisation will incentivise support for the left amongst LGBs. Liberal left-leaning parties in Western Europe have been paying more attention to the electoral potential of homosexual voters and have sought to take advantage of this prospective revenue of votes. Journalistic commentary highlights the shifts in party platforms and policy in efforts to capture the "pink vote" (Corujiera and Martín, 2007; Economist, 2015) and indeed the advances of gay rights legislation across the continent are all signals of political parties catering 
a supply to the political demands of LGB voters. Taking same-sex marriage legislation as an example of a core gay-rights issue, the provision of marriage to individuals of the same-sex has observed a marked growth across Europe in the last decade (Kollman \& Paternotte, 2013). Since the introduction of gay marriage in the Netherlands in 2001 , there are an additional fifteen countries in Europe that have legalised same-sex marriage.

In all of the European states where same-sex marriage was legalised via legislative reforms, with the exception of Sweden and the $\mathrm{UK}^{\mathrm{iv}}$, the legislation was introduced by either a social democratic party or a coalition government with leftist coalition partners. Moreover, the active role of left-leaning parties in promoting gay rights issues to appeal to homosexual voters, has often been accompanied by an active opposition to these issues amongst Christian democratic and conservative parties. That is not to say that centre-right parties are necessarily anti-gay (e.g. UK Conservative party under David Cameron). It is true, however, that parties on the right have launched quite aggressive political and, in some cases judicial, campaigns in opposition to gay rights issues particularly regarding the issue of same-sex marriage, and right-leaning parties have traditionally been the entrepreneurs of discriminatory policies against homosexuals. ${ }^{\mathrm{v}}$ Moreover, given the political right's position as the guardian of religious interests across most western European states (Broughton \& ten Napel, 2000), opposition to gay rights issues is a natural electoral position for them to take in light of this key religious constituency. Since voters' associations between parties and certain ideological positions are "sticky" (Walgrave, Lefevere \& Tresch, 2012), the connection between right-leaning parties with an anti-gay stance will likely prove hard to shake off. In terms of issue-ownership, it is clear that the left's historical record if catering the policy output to match LGB policy interests and the right's opposition to these same issues means that the left and right serve as ideological 
cues for pro-gay and anti-gay stances respectively. As such, gay voters seeking to maximise their legal rights and civil protections should support parties on the left.

The left-right dimension is not the only axis of conflict that structures political space within the European context. The European political space is also structured by the green/alternative/libertarian vs. traditional/authoritarian/nationalist (GAL-TAN) cultural cleavage (Hooghe et al, 2002) over post-materialist issues, as well as divisions over European integration (Hix, 1999). Whilst this paper does not test LGB divergence on the EU-based dimension, it focuses on the traditional left-right axis whilst also testing for distinct behaviour between LGBs and comparable heterosexuals over the cultural GAL-TAN axis ${ }^{\mathrm{vi}}$. The theoretical assumptions explaining the "sexuality gap" highlight that the experience of being LGB will likely engender a shift in policy preferences that are actually more in line with leftist policy objectives such as greater social welfare provisions, given that being discriminated against drives support for ideas of social solidarity and "fairness" (Hertzog, 1996). While LGBs might be pulled towards the left as a means of maximizing their own gay-specific welfare, the theoretical expectations equally anticipate homosexuals to be attracted to leftist parties since the economic proposals these parties' campaign for are in line with their own socio-economic views (Bailey, 1999; Schaffner \& Senic, 2006) and conditions (Egan, 2012).

In light of the above, I present the following two hypotheses for submission to empirical testing:

H1: LGB individuals identify with a left-leaning ideology in comparison to heterosexual individuals.

H2: LGB individuals will be more likely to vote for left-of-centre political parties than heterosexual individuals. 
Here I hypothesise that despite the traditional explanations of electoral behaviour, sexuality will still display an independent effect on ideological identity and vote choice. Specifically, LGB voters are distinct from heterosexual voters after controlling for demographic characteristics as well as core predictors of ideology and vote choice, including that of: i) classbased ii) cultural, and iii) valence politics voting models.

\section{DATA AND OPERATIONALISATION}

Data was obtained from the eight rounds of the ESS which includes biennial cross-country survey responses from 2002 to 2017. The countries in the analysis include ten European Union (EU) member states - Belgium, Germany, Ireland, Finland, France, Netherlands, the UK, Portugal, Spain, and Sweden - with the addition of Norway and Switzerland and represent the countries from Western Europe with full and uninterrupted participation in the ESS.

The ESS allows one to infer the sexuality of respondents by taking advantage of the household composition data provided in the survey. The survey asks respondents to identify the additional individual(s) within the household as well as their relationship to them. ${ }^{\text {vii }}$ When respondents identified a member of their household as their "Husband/wife/partner" and the gender of the respondent matched the gender of this same household member, respondents were identified as being in a same-sex relationship, i.e. homosexual or bisexual. Respondents living with a spouse or partner whose gender did not match were identified as being in a different-sex relationship, i.e. heterosexual. ${ }^{\text {viii }}$ This approach of identifying homosexual individuals from the ESS is described and applied by Fischer (2016). The external validity of the approach is confirmed by Fischer, Kalmijn and Steinmetz (2016) who find a comparable proportion of 
homosexuals are identified using the same identification method utilising data from the Generations and Gender Program, and there is also parity with the numbers identified in other European (Ahmed and Hammarstedt, 2010) and US studies adopting a similar method (Black et al., 2000; Carpenter 2005). Applying the method of identifying homosexuals described to the twelve countries included in the analysis, of the total number of respondents $(\mathrm{N}=114,512)$, I identify $1.4 \%$ of the respondents as being LGB $(\mathrm{N}=1,609)^{\mathrm{ix}}$.

The main explanatory variable of interest is the sexuality $(L G B)$ of respondents and is captured as a simple binary variable. Using the method described above, individuals were coded as homosexual (1) and heterosexual (0). Single individuals were removed from the dataset to ensure like-for-like comparison. This is because there is no way to identify homosexuals who are unable to be identified as LGB without having a partner to do so and who likely also form a large minority of the single population. This method of selecting and identifying homosexuality based on household individuals has potential limitations in relation to the generalisability of the findings since the sample pool is limited to individuals who are living with each other and in a relationship.

In relation to the hypotheses stated above, there are two dependent variables. Firstly, ideology is reported via the self-declared ideological position of respondents. Individuals place themselves on an eleven-point ideological scale from 0 (left) to 10 (right). Individuals are identified as being left-wing if they identify with an ideological value less than five. The second dependent variable captures respondents' vote choice. The ESS records the retrospective vote choice of respondents in the most recent national election. The dichotomous variable (votedleft) indicates when an individual voted for a left-of-centre political party (1) or any other party (0). The categorisation of parties as being on the left (see Table A1 in appendix) relies on the party 
categories from the Comparative Manifesto Project (CMP). Here I replicate the identification strategy for leftist parties utilised elsewhere in the literature (Haupt 2010; Lacewell 2017; Sen \& Barry 2018; Turnbull-Dugarte 2019): operationalising left parties as those categorised in the CMP as green/ecological, communist/socialist or social democratic parties. Where parties included in the ESS were not included in the CMP list of parties, they were identified as such via their official party website.

A set of controls are included in an effort to isolate the independent effect of homosexuality on the dependent variables. These have been chosen to cater to prevalent understandings regarding the factors that shape ideological preferences and voting behaviour in Europe. Firstly, I include two general demographic variables: a dummy variable coded 1 for men and respondents' age in years in order to control for women and young voters being more likely to support leftist parties (DeVaus \& McAllister, 1989; Inglehart \& Norris, 2000).

Secondly, controls are added to cater to class-orientated cleavage structures (Dalton, 1996; Lipset \& Rokkan, 1967). Commonplace in the literature exploring the role of class-based voting and its effect of vote choice is the role of both respondents' education and income. Education is recorded in the ESS using a five-point a categorical variable with respondents recording the highest level of education achieved. Income is measured using a ten-point indicator that signals the income percentile to which each respondent belongs from the population of each country in a particular year.

In addition to class-based explanations of ideology and vote-choice, are centre-periphery and religious-based (both read cultural) cleavages. The latter, arguably, has been somewhat in decline across European democracies (Best, 2011; Dalton, 1996; Inglehart, 1977) although 
Bruce (2003) argues that religion's shaping role on preferences in Europe remains constant. The tendency of the religious has been to favour Christian democrat and conservative parties (Broughton \& ten Napel, 2000; Dalton, 1996) given the strong attempts of the right to court the religious vote in Europe, with secular society tending to favour leftist parties. Seeking to control for the potential influential role of religion that may be observed, the Religiosity of individuals is included in the model and is operationalised here as the self-reported expression of how religious an individual considers themselves (0-10 scale) with higher values denoting greater levels of religiosity.

Rural-urban divisions appear to play an increasing role in political preferences in Europe, with rural voters expressing an increased preference for right-of-centre parties and policies in comparison to urban voters. Of recent note, for example, is the great divide between rural and urban voters in the UK in relation to the Brexit vote and views on immigration (Clarke et al., 2017), with the same too being noted as an explanatory factor in the success of Emmanuel Macron in France (Emanuele, 2018). I incorporate a categorical variable, domicile, to control for how urban or rural a respondent's location is.

Additionally, valence politics represents an important motivation for vote-choice (Clarke et al., 2017; Clarke et al., 2011; Stokes, 1992). The principal assumption of this model of electoral behaviour is that individuals' political preferences are driven by their appraisal of government performance. To control for the potential of valence politics, two additional indicators are included to capture respondents' feeling on the state of their country. Individuals report their current perception of the state of the economy as well as their level of satisfaction with democracy, both of which are scaled 0-10 with higher values representing a better evaluation of the economy and a higher level of satisfaction with democracy respectively. Voters with 
negative assessments of the economy also tend to belong to those identified as the economically "left behind" who have been moving their electoral support away from the traditional social democratic parties (Ford and Goodwin, 2014). The impact of the financial crisis caused a collapse in satisfaction with democracy amongst the voters of those member states subjected to the EU's financial bail-out conditions (Ruiz-Rufino and Alonso, 2017) which is also linked to a collapse in the electoral support for the mainstream left (Alonso and Ruiz-Rufino, 2018).

Finally, because the structure of the data represents a pooled collection of independent crosssectional surveys across time, both country-level and year effects will be included in the models. ${ }^{\mathrm{x}}$ Importantly, these dummies, in tandem with the valence politics indicators, will ensure that exogenous confounding forces, such as the arrival of the financial crisis in 2008 and the Eurozone crisis in 2010 which have shaped electoral outcomes and voting behaviour in many member states (Hernandez \& Kriesi, 2016), will also be controlled for.

\section{ANALYSIS}

Table 1 tests the first hypothesis and presents the results of logistic regression models ${ }^{\mathrm{xi}}$ estimating individuals' identification with the left. The estimation output reports both the logistic coefficient as well as the average marginal effect (AME) for ease of interpretation. Average marginal effects - reported in the tables and figures as percentage-points - are useful for providing an intuitive depiction of the substantive impact of the explanatory variables whilst holding the effect of the other independent variables constant. 
Table 1: Sexuality and ideology

\begin{tabular}{|c|c|c|c|c|}
\hline & \multicolumn{2}{|c|}{ (Model 1) } & \multicolumn{2}{|c|}{ (Model 2) } \\
\hline & Coef. & AME & Coef. & AME \\
\hline LGB & $0.38 * * *$ & $8.3 * * *$ & $0.33 * * *$ & $7.1 * * *$ \\
\hline Gender (1 male) & $\begin{array}{c}(0.00) \\
0.01 \\
(0.02)\end{array}$ & $\begin{array}{c}0.3 \\
(0.4)\end{array}$ & $\begin{array}{c}-0.08 * * * \\
(0.02)\end{array}$ & $\begin{array}{c}-1.7^{* * * *} \\
(0.5)\end{array}$ \\
\hline Age & $\begin{array}{c}-0.00 * * * \\
(0.00)\end{array}$ & $\begin{array}{c}-0.1^{* * * *} \\
(0.0)\end{array}$ & $\begin{array}{c}-0.00 \\
(0.00)\end{array}$ & $\begin{array}{l}-0.0 \\
(0.0)\end{array}$ \\
\hline \multicolumn{5}{|c|}{ Education (base: primary) } \\
\hline Low secondary & $\begin{array}{l}-0.01 \\
(0.04)\end{array}$ & $\begin{array}{l}-0.3 \\
(0.8)\end{array}$ & $\begin{array}{l}-0.08^{*} \\
(0.04)\end{array}$ & $\begin{array}{l}-1.6^{*} \\
(0.8)\end{array}$ \\
\hline High secondary & $\begin{array}{c}0.03 \\
(0.04)\end{array}$ & $\begin{array}{c}0.6 \\
(0.8)\end{array}$ & $\begin{array}{l}-0.06 \\
(0.04)\end{array}$ & $\begin{array}{l}-1.2 \\
(0.8)\end{array}$ \\
\hline Post-secondary & $\begin{array}{c}0.27 * * * \\
(0.06)\end{array}$ & $\begin{array}{c}5.8 * * * \\
(1.2)\end{array}$ & $\begin{array}{c}0.20 * * * \\
(0.06)\end{array}$ & $\begin{array}{c}4.2 * * * \\
(1.2)\end{array}$ \\
\hline Higher education & $\begin{array}{c}0.48 * * * \\
(0.04)\end{array}$ & $\begin{array}{c}10.6^{* * *} * \\
(0.8)\end{array}$ & $\begin{array}{c}0.40 * * * \\
(0.04)\end{array}$ & $\begin{array}{c}8.7 * * * \\
(0.9)\end{array}$ \\
\hline Income & $\begin{array}{l}-0.00 \\
(0.00)\end{array}$ & $\begin{array}{l}-0.0 \\
(0.1)\end{array}$ & $\begin{array}{c}-0.01 \\
(0.00)\end{array}$ & $\begin{array}{l}-0.1 \\
(0.1)\end{array}$ \\
\hline Religiosity & & & $\begin{array}{c}-0.11 * * * \\
(0.00)\end{array}$ & $\begin{array}{c}-2.3 * * * \\
(0.1)\end{array}$ \\
\hline \multicolumn{5}{|c|}{ Domicile (base: City/urban) } \\
\hline City suburbs & & & $\begin{array}{c}-0.19 * * * \\
(0.04)\end{array}$ & $\begin{array}{c}-4.1 * * * \\
(0.9)\end{array}$ \\
\hline Town/small city & & & $\begin{array}{c}-0.26 * * * \\
(0.03)\end{array}$ & $\begin{array}{c}-5.7 * * * \\
(0.7)\end{array}$ \\
\hline Village & & & $\begin{array}{c}-0.38 * * * \\
(0.03)\end{array}$ & $\begin{array}{c}-8.3 * * * * \\
(0.7)\end{array}$ \\
\hline Country/farm & & & $\begin{array}{c}-0.54 * * * \\
(0.05)\end{array}$ & $\begin{array}{c}-11.5^{* * * *} \\
(1.1)\end{array}$ \\
\hline View of economy & & & $\begin{array}{c}-0.04 * * * \\
(0.01)\end{array}$ & $\begin{array}{c}-0.9 * * * \\
(0.1)\end{array}$ \\
\hline Sat. with democracy & & & $\begin{array}{c}0.00 \\
(0.01)\end{array}$ & $\begin{array}{c}.0 \\
(0.1)\end{array}$ \\
\hline Country effects & \multicolumn{2}{|c|}{$\sqrt{ }$} & \multicolumn{2}{|c|}{$\checkmark$} \\
\hline Year effects & \multicolumn{2}{|c|}{$\checkmark$} & \multicolumn{2}{|c|}{$\checkmark$} \\
\hline Constant & \multicolumn{2}{|c|}{$\begin{array}{c}-0.92 * * * \\
(0.07)\end{array}$} & \multicolumn{2}{|c|}{$\begin{array}{c}0.06 \\
(0.08)\end{array}$} \\
\hline Observations & \multicolumn{2}{|c|}{93,044} & \multicolumn{2}{|c|}{90,747} \\
\hline
\end{tabular}

Robust country clustered standard errors (two-tailed) in parentheses $* * * \mathrm{p}<0.01, * * \mathrm{p}<0.05, * \mathrm{p}<0.1$ 
Model 1 in Table 1 shows that LGBs are, on average, 8.3 percentage points more likely than heterosexuals to identify as left-of-centre after controlling for demographic and class-based characteristics. Being LGB reflects the expectations set out in H1 displaying a significantly positive effect identification with the left. Even after variables capturing cultural predictors of electoral behaviour and valence politics variables are controlled for, Model 2 shows that LGBs are still 7.1 percentage points more likely to identify on the left. Of note is that sexuality remains a powerful predictor of ideology, in terms of its substantive association compared to other variables.

LGB men and women not only possess political ideologies that are significantly more leftleaning than heterosexuals, they are also more likely to support leftist policy preferences. In order to test this, I replicate the specification described in Model 2 using support for economic redistribution - an economic policy position traditionally associated with the left - as a dichotomous dependent variable. Figure 1 (detailed regression output available in Table A4) compares the effect of being LGB on the probability of identifying with the left and the probability of supporting economic redistribution. As depicted, LGBs are more likely to be supportive of traditional left-wing economic policies, with gay voters observing an increase in the probability of supporting redistribution of five percentage points.

This provides support to the theoretical assumption that the experiences of being homosexual might also be reshaping individuals' preferences beyond those policies focused on the welfare of homosexuals themselves (Bailey, 1999). Whilst the evidence here might be limited in that the data only permits a test using one policy position, the evidence does support the conclusion that LGBs are more left-leaning both in the general spatial sense as well as in terms of concrete policy positions that imply state intervention with distributional consequences. 
Effect of LGB on ideology \& support for redistribution
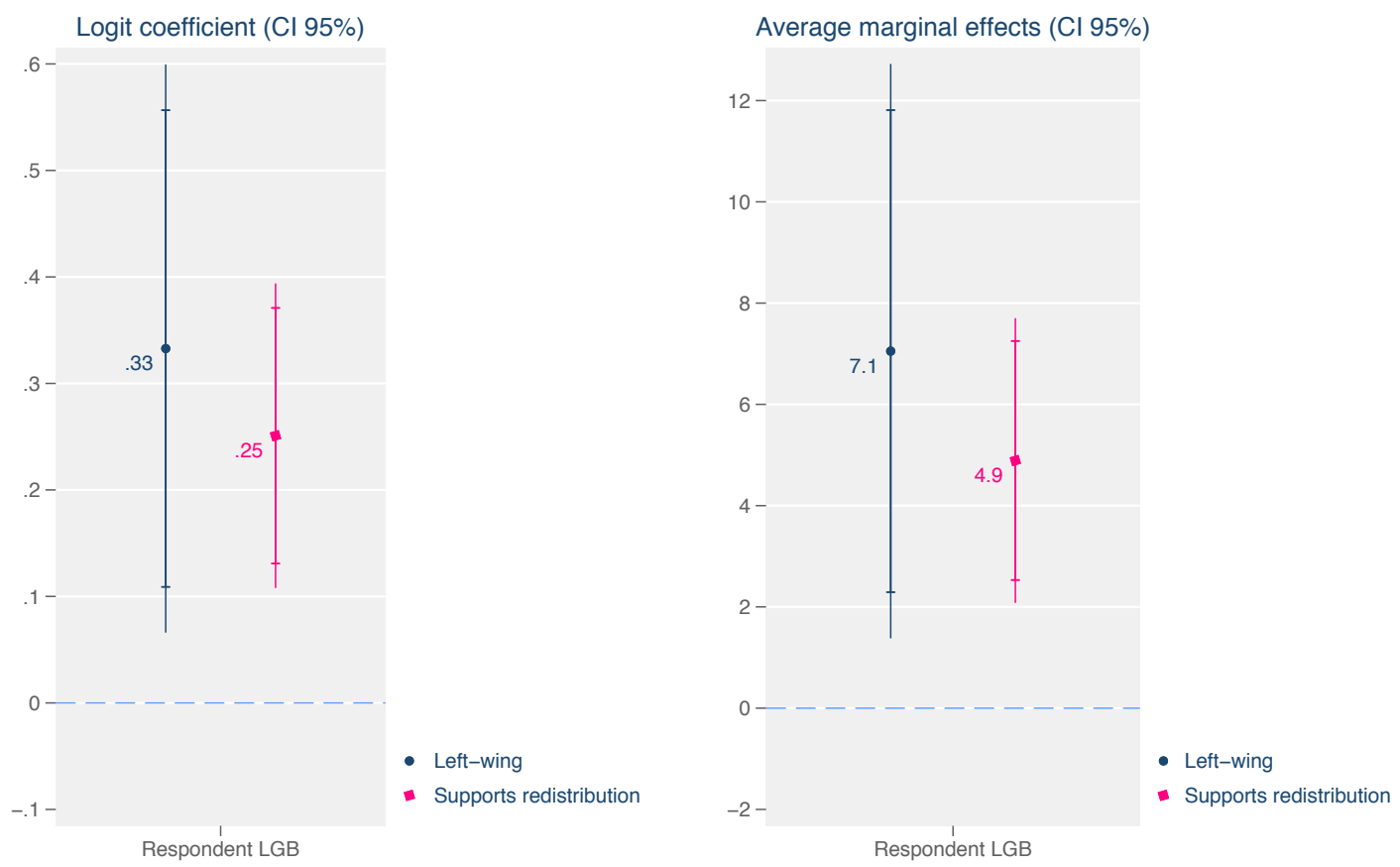

Figure 1: Sexuality and support for economic redistribution

Table 2 analyses the impact of sexuality on vote choice and provides empirical support for $\mathrm{H} 2$. Model 3 shows that LGBs are significantly more likely to support a leftist party than comparable heterosexuals when controlling for demographic and class-based elements, increasing the probability of voting for the left by a politically substantive nine percentage points. The positive effect of sexuality is underlined in Model 4 with the inclusion of the cultural and valence politics indicators, with LGBs being 7.2 percentage points more likely to vote for the left vis-à-vis comparable heterosexuals

The substantive role of sexuality remains noteworthy, surpassing the effects of religiosity, education and income. These findings support the argument that sexuality exhibits an independent and politically important effect on vote choice: namely that homosexuals exhibit 
a higher probability of voting for leftist parties. The results are not only significant but also substantive in comparison to explanations of traditional importance in the literature.

Table 2: Sexuality and vote choice

\begin{tabular}{|c|c|c|c|c|}
\hline & \multicolumn{2}{|c|}{ (Model 3) } & \multicolumn{2}{|c|}{ (Model 4) } \\
\hline & Coef. & AME & Coef. & AME \\
\hline LGB & $\begin{array}{c}0.38 * * * \\
(0.06)\end{array}$ & $\begin{array}{c}9.0 * * * \\
(1.5)\end{array}$ & $\begin{array}{c}0.32 * * * \\
(0.06)\end{array}$ & $\begin{array}{c}7.3 * * * \\
(1.4)\end{array}$ \\
\hline Gender (1 male) & $\begin{array}{c}-0.04 \\
(0.03)\end{array}$ & $\begin{array}{l}-1.0 \\
(0.6)\end{array}$ & $\begin{array}{c}-0.13 * * * \\
(0.03)\end{array}$ & $\begin{array}{c}-2.9 * * * \\
(0.8)\end{array}$ \\
\hline Age & $\begin{array}{l}-0.01 * \\
(0.00)\end{array}$ & $\begin{array}{l}-0.2 * \\
(0.1)\end{array}$ & $\begin{array}{c}-0.00 \\
(0.00)\end{array}$ & $\begin{array}{r}-0.1 \\
(.1)\end{array}$ \\
\hline \multicolumn{5}{|c|}{ Education (base: primary) } \\
\hline Low secondary & $\begin{array}{l}-0.14 \\
(0.14)\end{array}$ & $\begin{array}{l}-3.4 \\
(3.3)\end{array}$ & $\begin{array}{c}-0.19 * \\
(0.11)\end{array}$ & $\begin{array}{c}-4.4^{*} \\
(2.5)\end{array}$ \\
\hline High secondary & $\begin{array}{l}-0.25^{*} \\
(0.14)\end{array}$ & $\begin{array}{l}-5.9^{*} \\
(3.3)\end{array}$ & $\begin{array}{c}-0.32 * * * \\
(0.11)\end{array}$ & $\begin{array}{c}-7.3 * * * \\
(2.7)\end{array}$ \\
\hline Post-secondary & $\begin{array}{l}-0.08 \\
(0.18)\end{array}$ & $\begin{array}{l}-1.9 \\
(4.3)\end{array}$ & $\begin{array}{c}-0.14 \\
(0.15)\end{array}$ & $\begin{array}{l}-3.3 \\
(3.4)\end{array}$ \\
\hline Higher education & $\begin{array}{c}-0.04 \\
(0.16)\end{array}$ & $\begin{array}{l}-1.0 \\
(3.9)\end{array}$ & $\begin{array}{c}-0.14 \\
(0.13)\end{array}$ & $\begin{array}{l}-3.3 \\
(3.1)\end{array}$ \\
\hline Income & $\begin{array}{c}-0.03 * * * \\
(0.01)\end{array}$ & $\begin{array}{c}-0.8 * * * \\
(0.3)\end{array}$ & $\begin{array}{c}-0.04 * * * \\
(0.01)\end{array}$ & $\begin{array}{c}-1.0 * * * \\
(0.3)\end{array}$ \\
\hline Religiosity & & & $\begin{array}{c}-0.09 * * * \\
(0.02)\end{array}$ & $\begin{array}{c}-2.2 * * * \\
(0.4)\end{array}$ \\
\hline \multicolumn{5}{|c|}{ Domicile (base: City/urban) } \\
\hline City suburbs & & & $\begin{array}{c}-0.15 * * * \\
(0.05)\end{array}$ & $\begin{array}{c}-3.7 * * * \\
(1.3)\end{array}$ \\
\hline Town/small city & & & $\begin{array}{c}-0.29 * * * \\
(0.09)\end{array}$ & $\begin{array}{c}-7.0 * * * \\
(2.2)\end{array}$ \\
\hline Village & & & $\begin{array}{c}-0.51 * * * \\
(0.10)\end{array}$ & $\begin{array}{c}-12.0 * * * \\
(2.3)\end{array}$ \\
\hline Country/farm & & & $\begin{array}{c}-0.87 * * * \\
(0.22)\end{array}$ & $\begin{array}{c}-19.8 * * * \\
(4.8)\end{array}$ \\
\hline View of economy & & & $\begin{array}{l}-0.02 \\
(0.02)\end{array}$ & $\begin{array}{c}-0.6 \\
(0.4)\end{array}$ \\
\hline Sat. with democracy & & & $\begin{array}{c}0.03 * * * \\
(0.01)\end{array}$ & $\begin{array}{c}0.7 * * * \\
(0.3)\end{array}$ \\
\hline Country effects & $\sqrt{ }$ & & $\sqrt{2}$ & / \\
\hline Year effects & $\checkmark$ & & $v$ & / \\
\hline
\end{tabular}




\begin{tabular}{lcc} 
Constant & -0.10 & $0.70 * *$ \\
& $(0.40)$ & $(0.33)$ \\
Observations & 75,009 & 73,601 \\
\hline Robust country clustered standard errors (two-tailed) & in parentheses \\
& $* * * \mathrm{p}<0.01, * * \mathrm{p}<0.05, * \mathrm{p}<0.1$
\end{tabular}

\section{GAY VOTE IN A MULTIDIMENSIONAL SPACE}

Whilst the main focus has been on assessing LGB behaviour on the left-right dimension given the correlated dimensional space with the GAL-TAN axis in the majority of Western European states (Adams et al., 2005; Bakker et al., 2012) and the spatial utility of the left-right axis for voters (Rovny and Whitefield, 2019), I also test the effect of being LGB on parties across the cultural dimension.

Data provided by the Chapel Hill Expert Survey (CHES) provides estimations of political parties' policy position on a number of different political issues and provides an overall score for parties on both the traditional left-right dimension as well as the GAL-TAN cultural axis (Polk et al., 2017; Bakker et al., 2015). The CHES dataset categorises parties on the GAL-TAN axis on a range from 0 (Libertarian/Postmaterialist) to 10 (Traditional/Authoritarian). Parties closer to 0 are more supportive of issues such as same-sex marriage and abortion whilst parties closer to values of 10 promote "traditional" moral positions. Identifying parties with a GALTAN value smaller than five (detailed list of parties in Table A10) I assess the effect of being LGB on support for these parties and summarise the findings in Table 3. 
Table 3: Sexuality and vote choice in the GAL-TAN dimension

\begin{tabular}{lcccc}
\hline & \multicolumn{2}{c}{ (Model 5) } & \multicolumn{2}{c}{ (Model 6) } \\
& Coef. & AME & Coef. & AME \\
\hline & & & & \\
LGB & $0.34 * * *$ & $7.8 * * *$ & $0.31^{* * *}$ & $7.1 * * *$ \\
& $(0.07)$ & $(1.6)$ & $(0.07)$ & $(1.6)$ \\
Socio-economic controls & $\checkmark$ & \multicolumn{2}{c}{$\checkmark$} \\
Cultural \& valence controls & $X$ & $\checkmark$ \\
Country effects & $\checkmark$ & $\checkmark$ \\
Year effects & $\checkmark$ & $\checkmark$ \\
Observations & 78,706 & 76,684 \\
\hline
\end{tabular}

As in the case of leftist parties, LGBs observe a substantial increase in the probability of voting for a liberal-leaning party in Europe of around seven percentage points compared to their heterosexual peers. The consistency of this effect over the GAL-TAN dimension, however, is likely attributable to the coalesced nature of the economic and liberal dimensions in the countries under assessment here (Bakker et al., 2012). The majority of parties identified as being on the left were the same as those defined by CHES as being liberal with the latter group gaining a small number of notable liberal and centrist parties with pro-gay stances such as the Liberal Democrats in the UK or Ciudadanos in Spain. In the countries under assessment, a notable overlap exists across the two dimensions ${ }^{\mathrm{xii}}$ and, with the few exceptions included in Table A10, most parties are spatially placed along a singular left-liberal vs right-conservative political space as described by Kitschelt (1994: 24-26).

\section{ROBUSTNESS CHECKS}

To ensure the validity of the results presented for ideology and vote-choice, two robustness checks are carried out. Firstly, I test that the results are not dependent on the operationalisation choices made in designing the models. The estimations included in Table 1 and Table 2 are repeated using different forms of operationalising the battery of controls; applying alternative 
estimation techniques and; using gender-based subsamples, with the primary conclusions holding across these tests (see appendix). The findings are also robust with different compositions of countries and years (i.e. there is no country or ESS round that exhibits an influential effect over the model): the estimation of the full sample model is completed removing each of the twelve countries included in the estimation one-by-one with the main coefficient of LGB remaining significant throughout and I repeat the same process each ESS round (Figure A1 and A2).

As a second robustness check, I design a way of providing a tougher test for the impact of sexuality by decreasing the spread of extreme views expressed in the sample. Because the ideological preferences of individuals may be vast, it could be argued that the effect of sexuality exhibited in the models is only significant because LGBs are being compared to a much larger group of individuals within which there will be many extreme views. As part of the ESS, respondents are typically asked their views on a number of social or political issues. Respondents are asked to what extent they believe that homosexual individuals should be allowed to live freely. Using the responses of individuals to this question I can identify those individuals who express homophobic tendencies. ${ }^{\text {xii }}$ By limiting the sample of individuals and removing those with intolerant views towards homosexuality the effect of sexuality on both of the dependent variables is subjected to a tougher test. Effectively this means that individuals in same-sex relationships will only be compared with individuals in opposite-sex relationships who hold liberal or indifferent views towards homosexuality. In other words, socially liberal homosexuals will be compared with socially liberal heterosexuals. Figure 2 compares the coefficients of the regular models alongside those of the tough test with no homophobic respondents. As visualised, the associated impact of sexuality remains constant, reaffirming the positive confirmations of both $\mathrm{H} 1$ and $\mathrm{H} 2$. 

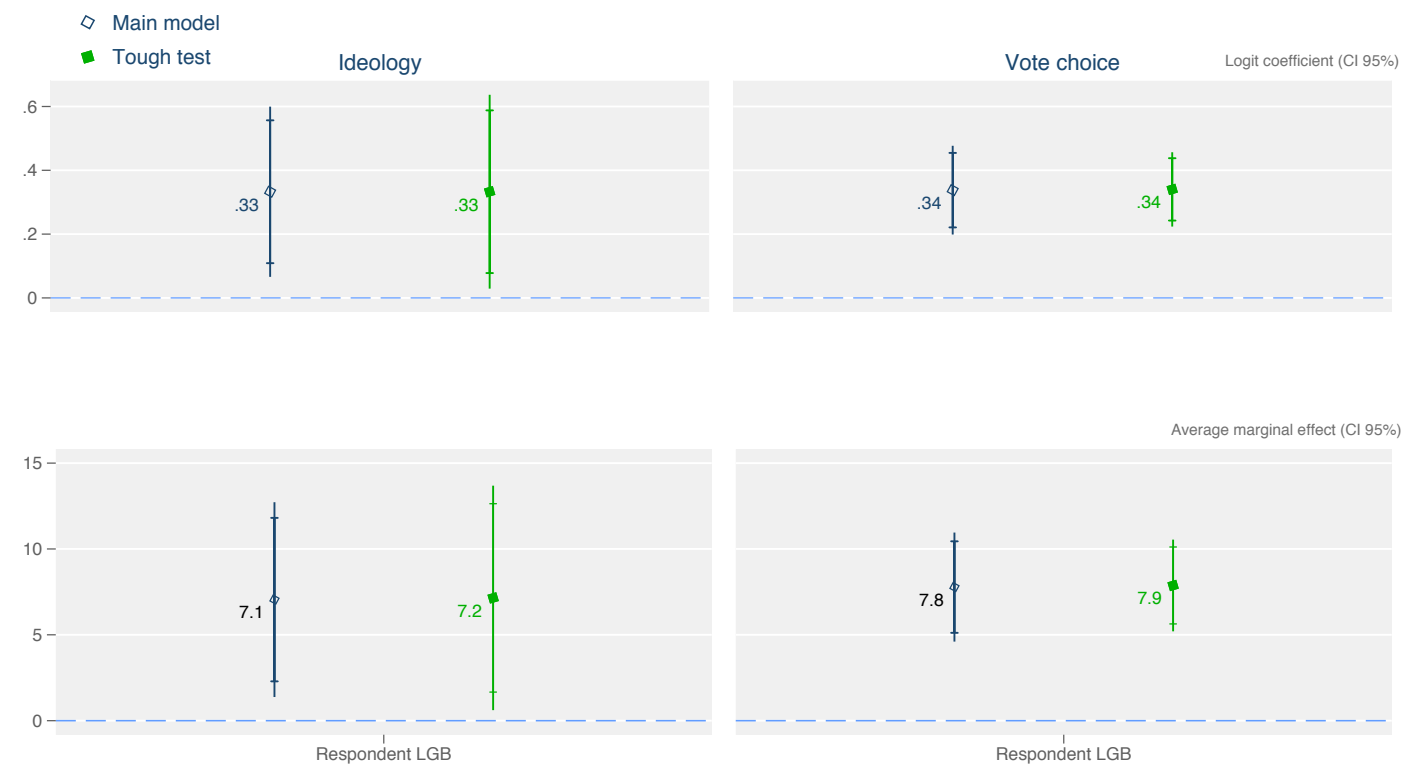

\section{Figure 2: Robustness check}

\section{DISCUSSION}

Sexuality matters in explaining the voting behaviour and ideological preferences of LGB voters in Europe. Building on the literature exploring the impact of sexuality on voting in the US, I hypothesised that i) LGBs would identify themselves more on the ideological left than nonLGBs, and ii) homosexuality would be associated with an increased probability of voting for a left-of-centre political party. I tested these hypotheses using cumulative data from the ESS between 2002 and 2017 for twelve Western European countries. The results of the analysis deliver support for these hypotheses and demonstrate that, as hypothesised, those in same-sex relationships were more likely to identify with the left and vote for leftist parties even after controlling for core determinants of vote choice in Western Europe. Homosexual individuals are more likely to vote for left-of-centre political parties and those with liberal stances on the 
GAL-TAN dimension. The findings for both hypotheses remain robust when catering for opposing arguments such as class-based cleavages, cultural and urban divides as well as valence politics. There is thus a clear independent "sexuality gap" (Hertzog, 1996) that shapes a voter's ideological preferences and electoral behaviour.

There are two potential mechanisms that can explain the distinct ideological preferences between LGB and non-LGB individuals and I echo these here, arguing that LGBs have likely underwent a learning process via their LGB experience that has altered their ideological predispositions to make them more supportive of leftist ideals; secondly that they are likely to be mobilised towards those who seek to cater to their aggregate policy preferences as a means of advancing their own welfare. The evidence presented here does not contradict these expectations but identifying the exact mechanism that explains the variation in preferences and vote choice based on sexuality merits further investigation to test these assumptions, especially in the context of the multidimensional political space in European countries.

As noted in earlier discussions, there are potential limitations to this analysis. The comparison of LGB persons relies on the indirect self-identification of LGB respondents. This means that there is no way of identifying single gay individuals who may make up a larger group of the total population and who may also display different political attitudes and preferences. Comparing the main findings to those of the US (Egan, 2012; Hertzog, 1996), the effect of sexuality wields an effect of comparative parity (Table A13). The methodological heterogeneity between these studies, however, particularly in terms of operationalising and identifying homosexual individuals, renders a direct comparison of effect sizes inappropriate. Of note, though, is that the addition of this study to the existing US-based literature forms the 
basis of a comparative and cross-national body of work that provides comparative evidentiary support for the existence of the sexuality gap in political behaviour.

For social scientists, this paper's findings demonstrate that sexuality is an explanatory variable of note that should be considered alongside traditional predictor variables of individual-level electoral outcomes. The results show that LGB men and women are more likely to i) be ideologically inclined towards the left and support typical leftist economic policies, and ii) vote for parties on the left that are presumed to cater to their policy objectives as well as socially liberal centrist parties. For parties on the right and authoritarian parties, this means that if they wish to secure the votes of these individuals, then they are tasked with ensuring that they are able to shake off sticky assumptions regarding traditional opposition to LGB rights issues. More research may seek to assess the efficacy of partisan attempts to promote LGB policies to their LGB audience, as this may allow one to better isolate the causal mechanism that drives LGB preferences for leftist parties and the ideological gap between LGBs and non-LGBs. It is still not clear whether LGBs prefer leftist parties because they cater to the policy needs directly related to their sexuality or because their sexuality has actually engendered preferences for traditionally leftist policy positions. To answer these questions and develop this line of research further, however, greater effort will need to be exerted to remedy the lack of data on these individuals in Europe in the first instance.

\footnotetext{
${ }^{\mathrm{i}}$ I refer here to LGBs in reference to individuals who participate in homosexual activity, that is sexual activity with members of the same-sex. Whilst I refer to the individuals in the study as being LGB, this does not mean that these same individuals adopt such labels themselves, since identification with the LGB identity is likely a political decision - see Egan (2012) for a detailed discussion and examination of the self-selection process of the LGB identity.

ii Theoretically there is ambiguity regarding what classes an individual as homosexual. I define homosexuality as being in a same-sex relationship. Whilst conscious of the limitations of this conceptualization - individuals may engage in same-sex sexual activity without considering themselves homosexuals (Egan, 2012; Fay, Turner, Klassen \& Gagnon, 1989; Kinsey, Pomeroy \& Martin, 1948) - I cannot distinguish between those who are in a same-sex (opposite-sex) relationship now and are perceived to be homosexual (heterosexual) but have
} 
had or would be willing to have a relationship with a partner of a different gender, i.e. bisexuals and non-conformers.

iii ILGA Europe's Annual Review provides by-country yearly reports on the state of LGB(T) rights laws across Europe : https://www.ilga-europe.org/rainboweurope

iv Introduced by the Conservative party in England and Wales only, introduced in Scotland by the Scottish National Party. Ireland held a referendum on the issue in 2015, and Austria introduced same-sex marriage following a ruling by the country's constitutional court in December 2017.

${ }^{v}$ For example: the main right-wing party in Spain (PP) filed a complaint with the country's Constitutional Court in response to the introduction of same-sex marriage by the governing socialist party (PSOE). The same PP also vowed to remove gay adoption rights from homosexuals if it won the 2008 general elections. The new right-wing challenger in Spain, Vox, also campaigned vehemently against the "gay agenda" in the 2019 general election (Turnbull-Dugarte, 2019). The outspokenly anti-gay position of far-right parties is echoed in Germany's Alternative for Germany (Arzheimer, 2015).

vi Whilst there is debate regarding the multiplicity of political dimensions in the European political space, I follow the arguments presented by Adams et al. (2005), Bakker et al. (2012), Kitschelt (1994) and Marks et al. (2006) who view the bloc of Western Europe as being primarily structured by a single dimension of political competition where the left-right and GAL-TAN cleavages are neatly nested and coalesced with one another so that political competition occurs across a singular left-liberal vs right-conservative axis (Kitschelt, 1994: 2426). Correlation between the two dimensions provided in Table A9.

vii Questions: Looking at this card, what relationship is he/she to you? Answers (where applicable): a) Husband/wife/partner b) Son/daughter/adopted c) Parent/parent-in-law d) Other relative

e) Other non-relative.

viii Such a strategy is at risk of error caused by misreporting of gender, although the effect of the same is likely to understate the effect of the LGB variable rather than increase it. Importantly, Black et al., (2000) find that the random error experienced using this method on data from the US was actually quite small. Carpenter (2005) warns against aggregating bisexuals alongside lesbians and gays given that they report significantly different responses across a catalogue of economic and demographic variables. Given the data, however, I am unable to disaggregate $\mathrm{LG}(+\mathrm{B})$.

ix Cross-national comparisons presented in Table A2. Of the 1,609 LGB respondents identified, 1,248 made it into the final sample included in the main model $(1.4 \%$ of $\mathrm{N}=90,747)$.

x Sampling and population weights also applied. Using an election-specific indicator instead of country and year fixed effects does not alter the main conclusions (Table A14).

${ }^{x i}$ The estimation is repeated using a non-dichotomised operationalisation of ideology (Table A6): the findings remain unchanged. Clustering at the country-level is advisable given the level of variation across many of the variables will be heterogeneous between countries. The estimation is repeated using non-clustered standard errors (Table A7): the findings remain unchanged.

xii The correlation between votes for the different dimensional operationalisations is greater than 0.7 .

xiii Those who "strongly disagree" or "disagree" that homosexuals should be able to live freely. For a discussion of the potential bias in survey questions using different terms of "gays" vs. "homosexuals" see McCabe (2019). 


\section{Bibliography}

Abou-Chadi, T. \& Finnigan, R. (2019). Rights for Same-Sex Couples and Public Attitudes Toward Gays and Lesbians in Europe. Comparative Political Studies 52(6): 868-895.

Adam, B.D. (2003). The Defense of Marriage Act and American Exceptionalism: The 'Gay Marriage' Panic in the United States. Journal of the History of Sexuality 12: 259-276.

Adam, B.D., Duyvendak, J.W. \& Krouwel, A. (1999). The Global Emergence of Gay and Lesbian Politics: National Imprints of a Worldwide Movement. Philadelphia: Temple University Press.

Adams J.F., Merrill S.I. and Grofman B. (2005). A Unified Theory of Party Competition. New York: Cambridge University Press.

Ahmed, A.M. and Hammarstedt, M. (2010). Sexual orientation and earnings: a register databased approach to identify homosexuals. Journal of Population Economics 23(3): 835-849.

Alonso, S. and Ruiz-Rufino, R. (2018). The costs of responsibility for the political establishment of the Eurozone (1999-2015). Party Politics. OnlineFirst: https://doi.org/10.1177/1354068818766182

Altman, D. (2012). Homosexual: Oppression and Liberation. Queensland: University of Queensland Press.

Anderson, E.A. (2006). Out of the Closet and into the Courts. Michigan: Michigan University Press.

Arzheimer, K. (2015). The AfD: Finally a Successful Right-Wing Populist Eurosceptic Party for Germany?. West European Politics 38(3): 535-556.

Ayoub, P. \& Paternotte, D. (2014). LGBT Activism and the Making of Europe: A Rainbow Europe. Basingstoke, UK: Palgrave MacMillan.

Bailey, R.W. (1999). Gay Politics, Urban Politics. New York: Columbia University Press.

Bakker, R. et al. (2015) Measuring party positions in Europe: The Chapel Hill expert survey trend file, 1999-2010. Party Politics 21(1): 143-152.

Bakker, R. Jolly, S. \& Polk, J. (2012). Complexity in the European party space: Exploring dimensionality with experts. European Union Politics 13(2): 219-245.

Best, R.E. (2011). The Declining Electoral Relevance of Traditional Cleavage Groups. European Political Science Review 3(2): 279-300.

Black, D., Gates, G., Sanders, S. \& Taylor, L. (2000). Demographics of the Gay and Lesbian Population in the United States: Evidence from Available Systemic Data Sources. Demography 37(2): 139-154. 
Black, D., Sanders, S. and Taylor, L. (2007). The Economics of Lesbian and Gay Families. Journal of Economic Perspectives 21(2): 53-70.

Bronski, M. (2012). A Queer History of the United States. Boston: Beacon Press.

Broughton, D. \& ten Napel, H.M. eds. (2000). Religion and Mass Electoral Behaviour in Europe. Routledge: London.

Bruce, S. (2003). Politics and Religion. Oxford: Polity Press.

Bullert, G. (1987). The homosexual rights movement: Its ideology, goals, and tactics. Journal of Social, Political and Economic Studies 12: 3-27.

Bulman, M. (2017). Attacks on LGBT people surge almost $80 \%$ in UK over last four years. The Independent [online]. Available at: https://www.independent.co.uk/news/uk/homenews/gay-lgbt-hate-crimes-stats-rise-four-year-physical-verbal-homophobic-abusecommunity-a 7933126.html [Accessed 20 ${ }^{\text {th }}$ October 2018]

Button, J.W., Rienzo, B.A. and Wald, K.D. (1997). Private Lives, Public Conflicts: Battles over Gay Rights in American Communities. D.C: Congressional Quarterly Press.

Campbell, A., et al. (1960). The American Voter. New Jersey: John Wiley \& Sons.

Carpenter, C.S. (2005). Self-Reported Sexual Orientation and Earnings: Evidence from California. Industrial and Labour Relations Review 58(2): 258-273.

Cass, V.C. (1979). Homosexuality and Identity Formation: A Theoretical Model. Journal of Homosexuality 4(3): 219-235.

Clarke, H.D., Goodwin. M. \& Whiteley, P. (2017). Brexit: Why Britain Voted to Leave the European Union. Cambridge: Cambridge University Press.

Clarke, H.D., Sanders, D., Stewart, M. \& Whiteley, P. (2011). Valence Politics and Electoral Choice in Britain, 2010. Journal of Elections, Public Opinion and Parties 21(2): 237-253.

Cohan, A.S. (1982). Obstacles to equality: Government responses to the gay rights movement in the United States. Political Studies 30: 59-76.

Cook, T. E. (1999). The Empirical Study of Lesbian, Gay, and Bisexual Politics: Assessing the First Wave of Research. American Political Science Review 93: 679-692.

Corujiera, J. and Martín, F. (2007) ¿A dónde va a parar el voto gay?, El Confidencial [online], $22^{\text {nd }}$ May. Available at https://www.elconfidencial.com/espana/2007-05-22/a-donde-va-aparar-el-voto-gay-del-no-al-pp-al-electorado-silencioso-que-mira-con-el-bolsillo_508416/ [Accessed Abril 11 $1^{\text {th }}$ 2019]

Dalton, R. J. (1996). Citizen Politics: Public Opinion and Political Parties in Advanced Western Democracies. 2nd ed. London: Chatham House. 
DeVaus, D. \& McAllister, I. (1989). The Changing Politics of Women: Gender and Political Alignment in 11 Nations. European Journal of Political Research 17: 241-262.

Economist (2015) The Gay Vote: Coming Out. April 11 2015.

Edelman, M. (1993). Understanding the gay and lesbian vote in '92. Public Perspective 4: 3233.

Egan, P.J. (2012). Group Cohesion without Group Mobilization: The Case of Lesbians, Gays and Bisexuals. British Journal of Political Science 42:597-616.

Emanuele, V. (2018). The hidden cleavage of the French election: Macron, Le Penand the urban-rural conflict. In L. De Sio \& A. Paparo (eds.) The Year of the Challengers? Issues, public opinion, and elections in Western Europe in 2017. Rome, Italy: CISE.

Faderman, L. (2016). The Gay Revolution. New York: Simon \& Schuster.

Fay, R.E., Turner, C.F., Klassen, A.D. \& Gagnon, J.H. (1989). Prevalence and patterns of same-gender sexual contact among men. Science 243: 338-348.

Fischer, M. M. (2016). Identifying same-sex couple in cross-national survey data. In R. Meulemann, G.L.M. Kraaykamp \& M. Wittenberg (eds.), Nederland in context: Verschillen en overeenkomsten: Proceedings Vijfde Nederlandse Workshop European Social Survey. Amsterdam: Amsterdam University Press.

Fischer, M.M., Kalmijn, M. and Steinmetz, S. (2016). Does tolerance matter? A comparative study of well-being of persons in same-sex and mixed-sex unions across nine European countries. European Societies 18(5): 515-534.

Ford, R. and Goodwin, M.J. (2014). Revolt on the Right. Explaining Support for the Radical Right in Britain. London: Routledge.

Government Equalities Office, UK. (2018). National LGBT Survey: Research Report. https://www.gov.uk/government/consultations/national-lgbt-survey

Haider-Markel, D.P. (2010). Out and Running: Gay and Lesbian Candidates, Elections, and Policy Representation. Washington: Georgetown University Press.

Harry, J. (1986). Sampling gay men. Journal of Sex Research 22: 21-34.

Haupt, A.B. (2010) Parties' Responses to economic globalization what is left for the left and right for the right? Party Politics 16(1): 5-27.

Hernandez, E. \& Kriesi, H. (2016). The electoral consequences of the financial and economic crises in Europe. European Journal of Political Research 55: 203-224.

Hertzog, M. (1996). The Lavender Vote. Lesbians, Gay Men, and Bisexuals in American Electoral Politics. New York: New York University Press. 
Hix, S. (1999). Dimensions and alignments in European Union politics: Cognitive constraints and partisan responses. European Journal of Political Research 35: 69-125.

Huddy, L. (2013). From Group Identity to Political Cohesion and Commitment. In L. Huddy, D.O. Sears \& R. Jervis (eds.), Oxford Handbook of Political Psychology. Second Edition. Oxford: Oxford University Press, pp.737-773

Hooghe, L., Marks, G., Wilson, C.J. (2002). Does left/right structure party positions on European integration? Comparative Political Studies 35(8): 965-989.

Inglehart, R. (1977). The Silent revolution: Changing values and political styles among Western publics. Princeton, NJ: Princeton University Press.

Inglehart, R. and Norris, P. (2000). The Developmental Theory of the Gender Gap: Women's and Men's Voting Behaviour in Global Perspective. International Political Science Review 21(4): 441-463.

Kinsey, A.C., Pomeroy, W.B. \& Martin, C.E. (1948). Sexual Behaviour in the Human Male. Philadelphia: Saunders.

Kirtschelt, H. (1994). The Transformation of European Social Democracy. Cambridge: Cambridge University Press.

Klarman, M.J. (2012). From the Closet to the Alter. Courts, Backlash, and the Struggle for Same-Sex Marriage. Oxford: Oxford University Press.

Kollman, K. (2017). Pioneering marriage for same-sex couples in the Netherlands. Journal of European Public Policy 24: 100-118.

Kollman, K. \& Paternotte, D. (2013). Regulating intimate relationships in the European polity: same-sex unions and policy convergence. Social Politics, 20: 510-533.

Lacewell, O.P. (2015). Beyond Policy Positions: how party type conditions programmatic responses to globalization pressures. Party Politics 23(4): 448-460.

Lewis, G.B. \& Oh, S.S. (2008). Public Opinion and State Action on Same-Sex Marriage. State and Local Government Review 40(1): 42-53.

Lewis, G.B., Rogers, M.A. \& Sherril, K. (2011). Lesbian, Gay and Bisexual Voters in the 2000 U.S. Presidential Election. Politics and Policy 39(5): 655-677.

Lipset, S.M. \& Rokkan, S. eds. (1967). Party Systems and Voter Alignments: Cross-National Perspectives. Toronto: The Free Press.

Magni, G. \& Reynolds, A. (2018.) Candidate Sexual Orientation Didn't Matter (in the Way You Might Think) in the 2015 UK General Election. American Political Science Review 112: 713-720. 
Marks G., Hooghe L., Nelson M, \& Edwards, E. (2006) Party Competition and European integration in the East and West. Different Structure, Same Causality. Comparative Political Studies 39(2): 155-175.

Martels, F. (2000) The Pink and the Black: Homosexuals in France Since 1968. Stanford: Stanford University Press.

Martin, J.L. and Dean, L. (1993). Developing a Community Sample of Gay Men for an Epidemiological Study of AIDS. in C.M. Renzetti and R.M. Lee (eds.), Researching Sensitive Topics. London: SAGE Publications.

Martin, J.I. and Knox, J. (2000) Methodological and Ethical Issues in Research on Lesbians and Gay Men. Social Work Research 24: 51-59.

McCabe, K.T. (2019) Person-positivity bias, social category labels, and attitudes towards gays and lesbians. Research \& Politics 6(3): 1-5. https://doi.org/10.1177/2053168019858850

McClennen, J.C. (2003). Researching Gay and lesbian domestic violence: the journey of a nonLGBT researcher. in W. Meezan and J.I. Martin (eds.), Research Methods with Gay, Lesbian, Bisexual and Transgender Populations., New York: Harrington Park Press.

McThomas, M. \& Buchanan, R.J. (2012). President Obama and Gay Rights: The 2008 and 2012 Presidential Elections. PS: Political Science and Politics 45(3): 424-448.

Mucciaroni, G. (2008). Same Sex, Different Politics: Success and Failure in the Struggle for Gay Rights. Chicago: University of Chicago Press.

Norris, P. \& Lovenduski, J. (1993). Gender and Party Politics in Britain. In P. Norris \& Lovenduski, J. (eds.), Gender and Party Politics London: Sage.

Polk, J. et al. (2017). Explaining the salience of anti-elitism and reducing political corruption for political parties in Europe with the 2014 Chapel Hill Expert Survey data. Research \& Politics 4(1): 1-9.

Portelli, C.J. (2004). Economic Analysis of Same-Sex Marriage. Journal of Homosexuality 47: 95-109.

Reynolds, A. (2013). Representation and Rights: The Impact of LGBT Legislators in Comparative Perspective. American Political Science Review 107: 259-274.

Rimmerman, C.A. (1996). Gay Rights, Military Wrongs. Political Perspectives on Lesbians and Gays in the Military. Abingdon: Routledge.

Rovny, J. and Whitefield, S. (2019). Issue dimensionality and party competition in turbulent times. Party Politics 25: 4-11

Ruiz-Rufino, R. and Alonso, S. (2017). Democracy without choice: Citizens' perceptions of government autonomy during the Eurozone crisis. European Journal of Political Research 56(2): 320-245. 
Schaffner, B. \& Senic, N. (2006). Rights or Benefits? Explaining the Sexual Identity Gap in American Political Behaviour. Political Research Quarterly 59(1): 123-132.

Sen, S. \& Barry, C.M. (2018). Economic globalization and the economic policy positions of parties. Party Politics. DOI: 10.1177/1354068818761179

Sherrill, K. (1996). The Political Power of Lesbians, Gays, and Bisexuals. PS: Political Science and Politics 29(3): 469-473.

Silberman, L. (2006). Same-sex Marriage: Refining the Conflict of Laws Analysis. University of Pennsylvania Law Review 153(6): 2195-2214.

Sommerlad, J. (2018). Section 28: What was Margaret Thatcher's controversial law and how did it affect the lives of LGBT+ people?, The Independent [online]. Available at: https://www.independent.co.uk/news/uk/politics/section-28-explained-lgbt-educationschools-homosexuality-gay-queer-margaret-thatcher-a8366741.html [Accessed 18th February 2019].

Stokes, D. (1992). Valence Politics. In D. Kavanagh (ed.), Electoral Politics. Oxford: Clarendon Press.

Sullivan, G. and Losberg, W. (2003). A study of Sampling in Research in the Field of Lesbian and Gay Studies. in W. Meezan and J.I. Martin (eds.), Research Methods with Gay, Lesbian, Bisexual and Transgender Populations. New York: Harrington Park Press.

Trappolin, K. Gaspirini, A. and Wintemute, R. eds. (2012). Confronting Homophobia in Europe. Social and Legal Perspectives. Oxford: Hart Publishing.

Turnbull-Dugarte, S.J. (2019). Explaining the end of Spanish exceptionalism and electoral support for Vox. Research and Politics 6(2): 1-8. https://doi.org/10.1177/2053168019851680

Turnbull-Dugarte, S.J. (2019). The impact of EU intervention on political parties' politicisation of Europe following the financial crisis. West European Politics. OnlineFirst: https://doi.org/10.1080/01402382.2019.1641779

Verba, S. and Nie, N.H. (1972). Political Participation in America. New York: Harper and Row.

Walgrave, S., Lefevere, J., and Tresch, A. (2012). The Associative Dimension of Issue Ownership. Public Opinion Quarterly 76(4): 771-782. 


\section{Appendix}

Table A 1: List of Left-of-centre parties in Western Europe

\begin{tabular}{|c|c|}
\hline Country & Parties \\
\hline $\mathrm{BE}$ - Belgium & $\begin{array}{l}\text { Groen(!) / AGALEV } \\
\text { SPA } \\
\text { Ecolo } \\
\text { Parti Socialiste }\end{array}$ \\
\hline $\mathrm{CH}$ - Switzerland & $\begin{array}{l}\text { Social democrats } \\
\text { Swiss Labour Party } \\
\text { Socialist Party } \\
\text { Green Party } \\
\text { Green Liberal Party } \\
\text { Alternative Left } \\
\text { Left }\end{array}$ \\
\hline DE - Germany & $\begin{array}{l}\text { SPD } \\
\text { PDS } \\
\text { Bundnis } 90 \\
\text { Die Grünen } \\
\text { Die Linke }\end{array}$ \\
\hline ES - Spain & $\begin{array}{l}\text { PSOE } \\
\text { Izquierda Unida } \\
\text { Podemos (and local variants) } \\
\end{array}$ \\
\hline FI - Finland & $\begin{array}{l}\text { The Green League } \\
\text { Finish Social Democratic Party } \\
\text { The Left Alliance } \\
\text { Communist Party of Finland } \\
\text { The Communist Workers' Party of Finland } \\
\text { Workers Party }\end{array}$ \\
\hline FR - France & $\begin{array}{l}\text { Parti communiste } \\
\text { Parti Socialiste } \\
\text { Les Verts } \\
\text { Parti Radical de Gauche } \\
\text { Front de Gauche }\end{array}$ \\
\hline GB - United Kingdom & $\begin{array}{l}\text { Labour Party } \\
\text { Green Party }\end{array}$ \\
\hline
\end{tabular}




\begin{tabular}{|l|l|}
\hline IE - Ireland & Labour Party \\
& Green Party \\
& United Left Alliance \\
& People Before profit \\
& Anti-austerity \\
& Socialist Party \\
& Social Democrats \\
\hline NL - Netherlands & Labour Party \\
& Democrats '66 \\
& Green Left \\
& Socialist Party \\
\hline NO - Norway & RØDT / RV \\
& Sosialistisk Venstreparti \\
& Arbeiderpartiet \\
& Miljøpartiet de Grønne \\
\hline PT - Portugal & Bloco de Esquerda \\
& Partido Comunista Português Partido Ecolo \\
& Partido Comunista dos Trabalhadores Portugueses \\
& Partido Operário de Unidade Socialista \\
& Partido Socialista \\
& Partido Social Democrata \\
& Coligação Democrática Unitária \\
\hline SE - Sweden & Socialdemokraterna \\
& Vänsterpartiet \\
& Miljöpartiet de gröna \\
\hline &
\end{tabular}


Table A 2: Identification of LGBs by country

\begin{tabular}{|l|l|}
\hline Country & \% of sample identified as LGB \\
\hline BE- Belgium & 2.1 \\
\hline CH- Switzerland & 1.3 \\
\hline DE - Germany & 1.7 \\
\hline ES- Spain & 0.9 \\
\hline FI -Finland & 0.9 \\
\hline FR - France & 1.9 \\
\hline GB - United Kingdom & 1.3 \\
\hline IE - Ireland & 2.6 \\
\hline NL - Netherlands & 1.5 \\
\hline NO - Norway & 0.9 \\
\hline PT - Portugal & 0.7 \\
\hline SE- Sweden & 1.1 \\
\hline Total sample & $\mathbf{1 . 4}$ \\
\hline
\end{tabular}

Table A 3: Mean values of the dependent variable and controls by sexuality (standard deviation)

\begin{tabular}{|l|l|l|}
\hline Variable & LGB respondents & Non-LGB respondents \\
\hline L/R position & $4.74(2.09)$ & $5.10(2.04)$ \\
\hline Gender & $0.57(0.50)$ & $0.51(0.5)$ \\
\hline Age & $46.89(15.17)$ & $50.73(15.15)$ \\
\hline Education & $3.52(1.37)$ & $3.30(1.42)$ \\
\hline Income & $6.61(2.53)$ & $6.62(2.42)$ \\
\hline Religiosity & $4.07(2.99)$ & $4.56(2.90)$ \\
\hline Domicile & $2.86(1.26)$ & $3.11(1.18)$ \\
\hline View of economy & $4.86(2.45)$ & $5.07(2.43)$ \\
\hline Satisfaction with democracy & $5.62(2.35)$ & $5.73(2.31)$ \\
\hline
\end{tabular}


Table A 4: Logistic regression modelling support for redistribution

Support for distribution

\begin{tabular}{lc} 
LGB & $0.25^{* * *}$ \\
& $(0.07)$ \\
Gender (1 male) & $-0.23^{* * *}$ \\
& $(0.02)$ \\
Age & $0.00^{*}$ \\
& $(0.00)$ \\
Education (base: primary) & \\
Low secondary & -0.03 \\
& $(0.06)$ \\
High secondary & $-0.11^{* *}$ \\
& $(0.06)$ \\
Post-secondary & $-0.17^{* * *}$ \\
& $(0.05)$ \\
Higher education & $-0.35^{* * *}$ \\
& $(0.03)$ \\
Income & $-0.13^{* * *}$ \\
& $(0.01)$ \\
Religiosity & $-0.03^{* *}$ \\
& $(0.01)$ \\
Domicile (base: City/urban) & \\
City suburbs & -0.06 \\
& $(0.05)$ \\
Town/small city & -0.07 \\
& $(0.07)$ \\
Village & -0.09 \\
& $(0.07)$ \\
Country/farm & -0.11 \\
& $(0.08)$ \\
View of economy & -0.02 \\
& $(0.02)$ \\
Sat. with democracy & $-0.06^{* * *}$ \\
Country effects & $(0.01)$ \\
Year effects & $\checkmark$ \\
Constant & $(0.28)$ \\
& 90,747 \\
\hline & \\
& \\
&
\end{tabular}

Robust country clustered standard errors (two-tailed) in parentheses $* * * \mathrm{p}<0.01, * * \mathrm{p}<0.05, * \mathrm{p}<0.1$ 


\section{Tests of different operationalisations of control variables}

Summary: The following re-operationalisation tests are carried out:

a) Education is operationalised as a continuous variable measuring the total number of years in education;

b) Income satisfaction is indicated as a substitute for self-reported income,

c) Religiosity is operationalised as a categorical variable indicating church attendance. 
Table A 5: Operationalisation sensitivity tests

\begin{tabular}{|c|c|c|c|c|c|c|}
\hline & \multicolumn{3}{|c|}{ Vote choice } & \multicolumn{3}{|c|}{ Ideology } \\
\hline & Education & Income & Religiosity & Education & Income & Religiosity \\
\hline LGB & $\begin{array}{c}0.32 * * * \\
(0.06)\end{array}$ & $\begin{array}{c}0.22 * * * \\
(0.05)\end{array}$ & $\begin{array}{c}0.32 * * * \\
(0.06)\end{array}$ & $\begin{array}{c}0.33 * * \\
(0.14)\end{array}$ & $\begin{array}{c}0.30 * * * \\
(0.09)\end{array}$ & $\begin{array}{c}0.33 * * \\
(0.14)\end{array}$ \\
\hline Gender (1 male) & $\begin{array}{c}-0.13 * * * \\
(0.03)\end{array}$ & $\begin{array}{c}-0.12 * * * \\
(0.03)\end{array}$ & $\begin{array}{c}-0.09 * * * \\
(0.03)\end{array}$ & $\begin{array}{l}-0.08^{*} \\
(0.04)\end{array}$ & $\begin{array}{l}-0.07 \\
(0.05)\end{array}$ & $\begin{array}{l}-0.03 \\
(0.05)\end{array}$ \\
\hline Age & $\begin{array}{l}-0.00 \\
(0.00)\end{array}$ & $\begin{array}{l}-0.00 \\
(0.00)\end{array}$ & $\begin{array}{c}-0.00 \\
(0.00)\end{array}$ & $\begin{array}{l}0.00 * \\
(0.00)\end{array}$ & $\begin{array}{l}-0.00 \\
(0.00)\end{array}$ & $\begin{array}{l}-0.00 \\
(0.00)\end{array}$ \\
\hline Low secondary & & $\begin{array}{c}-0.24^{* *} \\
(0.10)\end{array}$ & $\begin{array}{l}-0.19^{*} \\
(0.11)\end{array}$ & & $\begin{array}{c}-0.15^{* *} \\
(0.06)\end{array}$ & $\begin{array}{l}-0.07 \\
(0.09)\end{array}$ \\
\hline High secondary & & $\begin{array}{c}-0.38 * * * \\
(0.09)\end{array}$ & $\begin{array}{c}-0.30 * * * \\
(0.11)\end{array}$ & & $\begin{array}{c}-0.13^{* *} \\
(0.05)\end{array}$ & $\begin{array}{l}-0.03 \\
(0.07)\end{array}$ \\
\hline Post-secondary & & $\begin{array}{l}-0.27^{*} \\
(0.15)\end{array}$ & $\begin{array}{c}-0.14 \\
(0.14)\end{array}$ & & $\begin{array}{c}0.13 * * \\
(0.07)\end{array}$ & $\begin{array}{c}0.21 * * * \\
(0.07)\end{array}$ \\
\hline Higher education & & $\begin{array}{c}-0.24^{* *} \\
(0.12)\end{array}$ & $\begin{array}{l}-0.11 \\
(0.13)\end{array}$ & & $\begin{array}{c}0.32 * * * \\
(0.07)\end{array}$ & $\begin{array}{c}0.44 * * * \\
(0.08)\end{array}$ \\
\hline Education (years) & $\begin{array}{c}0.01 \\
(0.01)\end{array}$ & - & - & $\begin{array}{c}0.05 * * * \\
(0.02)\end{array}$ & - & - \\
\hline Income & $\begin{array}{c}-0.05 * * * \\
(0.02)\end{array}$ & - & $\begin{array}{c}-0.04 * * * \\
(0.01)\end{array}$ & $\begin{array}{l}-0.01 \\
(0.00)\end{array}$ & - & $\begin{array}{l}-0.00 \\
(0.01)\end{array}$ \\
\hline Income sat. & - & $\begin{array}{c}-0.14 * * * \\
(0.03)\end{array}$ & - & & $\begin{array}{l}-0.02 \\
(0.03)\end{array}$ & - \\
\hline Religiosity & $\begin{array}{c}-0.09 * * * \\
(0.02)\end{array}$ & $\begin{array}{c}-0.09 * * * \\
(0.02)\end{array}$ & - & $\begin{array}{c}-0.11 * * * \\
(0.01)\end{array}$ & $\begin{array}{c}-0.11 * * * \\
(0.02)\end{array}$ & - \\
\hline Weekly church & - & - & $\begin{array}{c}-0.86 * * * \\
(0.24)\end{array}$ & - & - & $\begin{array}{c}-0.81 * * * \\
(0.16)\end{array}$ \\
\hline Occasional church & - & - & $\begin{array}{c}-0.41 * * * \\
(0.06)\end{array}$ & - & - & $\begin{array}{c}-0.45^{* * * *} \\
(0.07)\end{array}$ \\
\hline City suburbs & $\begin{array}{c}-0.14 * * * \\
(0.05)\end{array}$ & $\begin{array}{c}-0.15 * * * \\
(0.06)\end{array}$ & $\begin{array}{c}-0.15 * * * \\
(0.05)\end{array}$ & $\begin{array}{c}-0.18 * * * \\
(0.03)\end{array}$ & $\begin{array}{c}-0.18 * * * \\
(0.05)\end{array}$ & $\begin{array}{c}-0.19 * * * \\
(0.03)\end{array}$ \\
\hline Town/small city & $\begin{array}{c}-0.29 * * * \\
(0.08)\end{array}$ & $\begin{array}{c}-0.26^{* * *} \\
(0.10)\end{array}$ & $\begin{array}{c}-0.29 * * * \\
(0.09)\end{array}$ & $\begin{array}{c}-0.26 * * * \\
(0.04)\end{array}$ & $\begin{array}{c}-0.23 * * * \\
(0.07)\end{array}$ & $\begin{array}{c}-0.26^{* * *} \\
(0.05)\end{array}$ \\
\hline Village & $\begin{array}{c}-0.50 * * * \\
(0.09)\end{array}$ & $\begin{array}{c}-0.47 * * * \\
(0.11)\end{array}$ & $\begin{array}{c}-0.50 * * * \\
(0.10)\end{array}$ & $\begin{array}{c}-0.38 * * * \\
(0.07)\end{array}$ & $\begin{array}{c}-0.35 * * * \\
(0.09)\end{array}$ & $\begin{array}{c}-0.38^{* * * *} \\
(0.07)\end{array}$ \\
\hline Country/farm & $\begin{array}{c}-0.86 * * * \\
(0.23)\end{array}$ & $\begin{array}{c}-0.87 * * * \\
(0.23)\end{array}$ & $\begin{array}{c}-0.86 * * * \\
(0.22)\end{array}$ & $\begin{array}{c}-0.53 * * * \\
(0.05)\end{array}$ & $\begin{array}{c}-0.50 * * * \\
(0.06)\end{array}$ & $\begin{array}{c}-0.54 * * * \\
(0.05)\end{array}$ \\
\hline View of economy & $\begin{array}{c}-0.02 \\
(0.02)\end{array}$ & $\begin{array}{l}-0.01 \\
(0.01)\end{array}$ & $\begin{array}{c}-0.02 * \\
(0.01)\end{array}$ & $\begin{array}{c}-0.04 * * * \\
(0.01)\end{array}$ & $\begin{array}{c}-0.04 * * * \\
(0.01)\end{array}$ & $\begin{array}{c}-0.04 * * * \\
(0.01)\end{array}$ \\
\hline Sat. with democracy & $\begin{array}{l}0.03 * * \\
(0.01)\end{array}$ & $\begin{array}{c}0.04 * * * \\
(0.01)\end{array}$ & $\begin{array}{l}0.03 * * \\
(0.01)\end{array}$ & $\begin{array}{c}0.00 \\
(0.01)\end{array}$ & $\begin{array}{c}0.01 \\
(0.01)\end{array}$ & $\begin{array}{l}-0.00 \\
(0.01)\end{array}$ \\
\hline Country effects & $\checkmark$ & $\checkmark$ & $\checkmark$ & $\checkmark$ & $\checkmark$ & $\checkmark$ \\
\hline Year effects & $\checkmark$ & $\checkmark$ & $\checkmark$ & $\checkmark$ & $\checkmark$ & $\checkmark$ \\
\hline Constant & $\begin{array}{c}0.31 \\
(0.36)\end{array}$ & $\begin{array}{l}0.75^{* *} \\
(0.31)\end{array}$ & $\begin{array}{c}0.46 \\
(0.37)\end{array}$ & $\begin{array}{c}-0.60 * * \\
(0.29)\end{array}$ & $\begin{array}{c}0.10 \\
(0.09)\end{array}$ & $\begin{array}{c}-0.22 * * \\
(0.09)\end{array}$ \\
\hline Observations & 73,637 & 86,998 & 73,656 & 90,812 & 107,737 & 90,819 \\
\hline
\end{tabular}

Robust country clustered standard errors (two-tailed) in parentheses 
Table A 6: Modelling ideology as a continuous variable

\begin{tabular}{|c|c|c|c|c|}
\hline \multirow[b]{2}{*}{ LGB } & \multicolumn{2}{|c|}{$\begin{array}{c}\text { Ideology }^{\dagger}(0-10) \\
\text { OLS }\end{array}$} & \multicolumn{2}{|c|}{$\begin{array}{l}\text { Ideology dummy } \\
\text { Logistic regression }\end{array}$} \\
\hline & $\begin{array}{c}0.32 * * * \\
(0.10)\end{array}$ & $\begin{array}{l}0.26 * * \\
(0.09)\end{array}$ & $\begin{array}{c}0.38 * * * \\
(0.08)\end{array}$ & $\begin{array}{c}0.33 * * * \\
(0.08)\end{array}$ \\
\hline Gender (1 male) & $\begin{array}{c}-0.14^{* *} \\
(0.05)\end{array}$ & $\begin{array}{c}-0.22 * * * \\
(0.03)\end{array}$ & $\begin{array}{c}0.01 \\
(0.02)\end{array}$ & $\begin{array}{c}-0.08 * * * \\
(0.02)\end{array}$ \\
\hline Age & $\begin{array}{c}-0.01 * * * \\
(0.00)\end{array}$ & $\begin{array}{c}-0.01 * * * \\
(0.00)\end{array}$ & $\begin{array}{c}-0.00 * * * \\
(0.00)\end{array}$ & $\begin{array}{l}-0.00 \\
(0.00)\end{array}$ \\
\hline Education (base: primary) & & & & \\
\hline Low secondary & $\begin{array}{c}0.01 \\
(0.13)\end{array}$ & $\begin{array}{l}-0.05 \\
(0.10)\end{array}$ & $\begin{array}{l}-0.01 \\
(0.04)\end{array}$ & $\begin{array}{l}-0.08^{*} \\
(0.04)\end{array}$ \\
\hline High secondary & $\begin{array}{l}-0.01 \\
(0.09)\end{array}$ & $\begin{array}{l}-0.07 \\
(0.08)\end{array}$ & $\begin{array}{c}0.03 \\
(0.04)\end{array}$ & $\begin{array}{l}-0.06 \\
(0.04)\end{array}$ \\
\hline Post-secondary & $\begin{array}{l}0.08 \\
(0.11)\end{array}$ & $\begin{array}{c}0.04 \\
(0.09)\end{array}$ & $\begin{array}{c}0.27 * * * \\
(0.06)\end{array}$ & $\begin{array}{c}0.20 * * * \\
(0.06)\end{array}$ \\
\hline Higher education & $\begin{array}{c}0.26 * * \\
(0.11)\end{array}$ & $\begin{array}{l}0.22 * * \\
(0.09)\end{array}$ & $\begin{array}{c}0.48 * * * \\
(0.04)\end{array}$ & $\begin{array}{c}0.40 * * * \\
(0.04)\end{array}$ \\
\hline Income & $\begin{array}{c}-0.05 * * * \\
(0.01)\end{array}$ & $\begin{array}{c}-0.04 * * * \\
(0.01)\end{array}$ & $\begin{array}{l}-0.00 \\
(0.00)\end{array}$ & $\begin{array}{l}-0.01 \\
(0.00)\end{array}$ \\
\hline Religiosity & & $\begin{array}{c}-0.12 * * * \\
(0.02)\end{array}$ & & $\begin{array}{c}-0.11 * * * \\
(0.00)\end{array}$ \\
\hline Domicile (base: City/urban) & & & & \\
\hline City suburbs & & $\begin{array}{c}-0.16^{* * *} \\
(0.04)\end{array}$ & & $\begin{array}{c}-0.19 * * * \\
(0.04)\end{array}$ \\
\hline Town/small city & & $\begin{array}{c}-0.22 * * * \\
(0.06)\end{array}$ & & $\begin{array}{c}-0.26 * * * \\
(0.03)\end{array}$ \\
\hline Village & & $\begin{array}{c}-0.35 * * * \\
(0.08)\end{array}$ & & $\begin{array}{c}-0.38 * * * \\
(0.03)\end{array}$ \\
\hline Country/farm & & $\begin{array}{c}-0.46 * * * \\
(0.07)\end{array}$ & & $\begin{array}{c}-0.54 * * * \\
(0.05)\end{array}$ \\
\hline View of economy & & $\begin{array}{c}-0.06^{* * *} \\
(0.01)\end{array}$ & & $\begin{array}{c}-0.04 * * * \\
(0.01)\end{array}$ \\
\hline Sat. with democracy & & $\begin{array}{c}-0.04 * * * \\
(0.01)\end{array}$ & & $\begin{array}{c}0.00 \\
(0.01)\end{array}$ \\
\hline Country effects & $\checkmark$ & $\checkmark$ & $\checkmark$ & $\checkmark$ \\
\hline Year effects & $\checkmark$ & $\checkmark$ & $\checkmark$ & $\checkmark$ \\
\hline Constant & $\begin{array}{c}5.83 * * * \\
(0.18)\end{array}$ & $\begin{array}{c}6.97 * * * \\
(0.24)\end{array}$ & $\begin{array}{c}-0.92 * * * \\
(0.07)\end{array}$ & $\begin{array}{c}0.06 \\
(0.08)\end{array}$ \\
\hline Observations & 87,888 & 86,416 & 93,044 & 90,747 \\
\hline
\end{tabular}

$\dagger 0=$ Right and $10=$ Left

Robust country clustered standard errors (two-tailed) in parentheses $* * * \mathrm{p}<0.01,{ }^{* *} \mathrm{p}<0.05,{ }^{*} \mathrm{p}<0.1$ 
Table A 7: Sensitivity test comparing clustering of standard errors

\begin{tabular}{|c|c|c|c|c|}
\hline & \multicolumn{2}{|c|}{ Ideology } & \multicolumn{2}{|c|}{ Vote choice } \\
\hline & $\begin{array}{c}\text { Clustered } \\
\text { SEs }\end{array}$ & $\begin{array}{c}\text { Non-clustered } \\
\text { SEs }\end{array}$ & $\begin{array}{l}\text { Clustered } \\
\text { SEs }\end{array}$ & $\begin{array}{c}\text { Non-clustered } \\
\text { SEs }\end{array}$ \\
\hline LGB & $\begin{array}{l}0.33 * * \\
(0.14)\end{array}$ & $\begin{array}{c}0.33 * * * \\
(0.08)\end{array}$ & $\begin{array}{c}0.32 * * * \\
(0.06)\end{array}$ & $\begin{array}{c}0.32 * * * \\
(0.09)\end{array}$ \\
\hline Gender (1 male) & $\begin{array}{l}-0.08^{*} \\
(0.05)\end{array}$ & $\begin{array}{c}-0.08 * * * \\
(0.02)\end{array}$ & $\begin{array}{c}-0.13 * * * \\
(0.03)\end{array}$ & $\begin{array}{c}-0.13 * * * \\
(0.02)\end{array}$ \\
\hline Age & $\begin{array}{l}-0.00 \\
(0.00)\end{array}$ & $\begin{array}{l}-0.00 \\
(0.00)\end{array}$ & $\begin{array}{l}-0.00 \\
(0.00)\end{array}$ & $\begin{array}{c}-0.00 * * * \\
(0.00)\end{array}$ \\
\hline $\begin{array}{l}\text { Education (base: } \\
\text { primary) }\end{array}$ & -0.08 & $-0.08^{*}$ & $-0.19 *$ & $-0.19 * * *$ \\
\hline Low secondary & $(0.09)$ & $(0.04)$ & $(0.11)$ & $(0.04)$ \\
\hline High secondary & $\begin{array}{c}-0.06 \\
(0.08) \\
0.20 * * *\end{array}$ & $\begin{array}{c}-0.06 \\
(0.04) \\
0.20^{* * *}\end{array}$ & $\begin{array}{c}-0.32 * * * \\
(0.11) \\
-0.14\end{array}$ & $\begin{array}{c}-0.32 * * * \\
(0.04) \\
-0.14 * *\end{array}$ \\
\hline Post-secondary & $\begin{array}{c}(0.07) \\
0.40^{* * *}\end{array}$ & $\begin{array}{c}(0.06) \\
0.40 * * *\end{array}$ & $\begin{array}{l}(0.15) \\
-0.14\end{array}$ & $\begin{array}{c}(0.06) \\
-0.14 * * *\end{array}$ \\
\hline $\begin{array}{l}\text { Higher education } \\
\text { Income }\end{array}$ & $\begin{array}{l}(0.08) \\
-0.01 \\
(0.01)\end{array}$ & $\begin{array}{l}(0.04) \\
-0.01 \\
(0.00)\end{array}$ & $\begin{array}{c}(0.13) \\
-0.04 * * * \\
(0.01)\end{array}$ & $\begin{array}{c}(0.04) \\
-0.04 * * * \\
(0.01)\end{array}$ \\
\hline Religiosity & $\begin{array}{c}-0.11 * * * \\
(0.01)\end{array}$ & $\begin{array}{c}-0.11 * * * \\
(0.00)\end{array}$ & $\begin{array}{c}-0.09 * * * \\
(0.02)\end{array}$ & $\begin{array}{c}-0.09 * * * \\
(0.00)\end{array}$ \\
\hline $\begin{array}{l}\text { Domicile (base: } \\
\text { City/urban) }\end{array}$ & $-0.19 * * *$ & $-0.19 * * *$ & $-0.15 * * *$ & $-0.15 * * *$ \\
\hline City suburbs & $\begin{array}{c}(0.03) \\
-0.26 * * *\end{array}$ & $\begin{array}{c}(0.04) \\
-0.26 * * *\end{array}$ & $\begin{array}{c}(0.05) \\
-0.29 * * *\end{array}$ & $\begin{array}{c}(0.04) \\
-0.29 * * *\end{array}$ \\
\hline Town/small city & $\begin{array}{c}(0.05) \\
-0.38 * * *\end{array}$ & $\begin{array}{c}(0.03) \\
-0.38 * * *\end{array}$ & $\begin{array}{c}(0.09) \\
-0.51 * * *\end{array}$ & $\begin{array}{c}(0.04) \\
-0.51 * * *\end{array}$ \\
\hline Village & $\begin{array}{c}(0.07) \\
-0.54 * * *\end{array}$ & $\begin{array}{c}(0.03) \\
-0.54 * * *\end{array}$ & $\begin{array}{c}(0.10) \\
-0.87 * * *\end{array}$ & $\begin{array}{c}(0.04) \\
-0.87 * * *\end{array}$ \\
\hline Country/farm & $\begin{array}{c}(0.05) \\
-0.04 * * *\end{array}$ & $\begin{array}{c}(0.05) \\
-0.04 * * *\end{array}$ & $\begin{array}{l}(0.22) \\
-0.02\end{array}$ & $\begin{array}{c}(0.06) \\
-0.02 * * *\end{array}$ \\
\hline View of economy & $\begin{array}{c}(0.01) \\
0.00\end{array}$ & $\begin{array}{c}(0.01) \\
0.00\end{array}$ & $\begin{array}{c}(0.02) \\
0.03 * * *\end{array}$ & $\begin{array}{c}(0.01) \\
0.03^{* * *}\end{array}$ \\
\hline Sat. with democracy & $\begin{array}{c}(0.01) \\
0.20 * * *\end{array}$ & $\begin{array}{c}(0.01) \\
0.20 * * *\end{array}$ & $\begin{array}{c}(0.01) \\
0.17 * * *\end{array}$ & $\begin{array}{c}(0.01) \\
0.17^{* * *}\end{array}$ \\
\hline Country effects & $(0.01)$ & $(0.04)$ & $(0.01)$ & $(0.05)$ \\
\hline Constant & $\begin{array}{c}0.06 \\
(0.09)\end{array}$ & $\begin{array}{c}0.06 \\
(0.08)\end{array}$ & $\begin{array}{c}0.70 * * \\
(0.33)\end{array}$ & $\begin{array}{c}0.70 * * * \\
(0.09)\end{array}$ \\
\hline Observations & 90,747 & 90,747 & 73,601 & 73,601 \\
\hline
\end{tabular}

Robust standard errors (two-tailed) in parentheses $* * * \mathrm{p}<0.01, * * \mathrm{p}<0.05, * \mathrm{p}<0.1$ 
Table A 8: Modelling effect of sexuality across gender subsamples

\begin{tabular}{lcccc}
\hline & \multicolumn{2}{c}{ Ideology } & \multicolumn{2}{c}{ Vote choice } \\
& Men & Women & Men & Women \\
\hline LGB & $0.22^{*}$ & $0.51^{* *}$ & $0.34^{* * *}$ & $0.31^{* * *}$ \\
& $(0.12)$ & $(0.22)$ & $(0.12)$ & $(0.08)$ \\
\hline Control variables & $\checkmark$ & $\checkmark$ & $\checkmark$ & $\checkmark$ \\
Country effects & $\checkmark$ & $\checkmark$ & $\checkmark$ & $\checkmark$ \\
Year effects & $\checkmark$ & $\checkmark$ & $\checkmark$ & $\checkmark$ \\
Observations & 46,841 & 43,906 & 38,434 & 35,167 \\
\hline \multicolumn{2}{c}{ Robust country clustered standard errors (two-tailed) in parentheses } \\
\end{tabular}

Table A 9: Correlation of political dimensions in countries included in analysis

\begin{tabular}{|c|c|c|}
\hline Country & $\begin{array}{l}\text { Correlation Coefficient } \\
\text { (Left-right / GAL-TAN }\end{array}$ & \\
\hline Belgium & 0.55 & \\
\hline Finland & 0.17 & \\
\hline France & 0.69 & \\
\hline Germany & -0.21 & \\
\hline Ireland & 0.49 & \\
\hline Netherlands & 0.30 & \\
\hline Portugal & 0.90 & \\
\hline Spain & 0.88 & \\
\hline Sweden & 0.50 & \\
\hline UK & $\mid \mathbf{0 . 7 3}$ & \\
\hline \multicolumn{3}{|c|}{ Note: Replication from Bakker et al. (2012). Norway and Switzerland not included } \\
\hline \multicolumn{3}{|c|}{ Table A 10: List of liberal parties and their GAL-TAN score } \\
\hline Country & Party & GAL-TAN position \\
\hline \multirow[t]{7}{*}{ BE - Belgium } & Groen(!) / AGALEV & 1.23 \\
\hline & SPA & 3.19 \\
\hline & Ecolo & 1.54 \\
\hline & Mouvement Réformateur & 4.13 \\
\hline & Parti Socialiste & 3.19 \\
\hline & PVDA & 2.53 \\
\hline & VLD & 3.46 \\
\hline \multirow[t]{6}{*}{ DE - Germany } & SPD & 4.25 \\
\hline & PDS & 4.06 \\
\hline & Bundnis 90 / Die Grünen & 1.72 \\
\hline & Die Linke & 4.06 \\
\hline & FDP & 3.39 \\
\hline & Piraten & 1.91 \\
\hline
\end{tabular}




\begin{tabular}{|c|c|c|}
\hline ES - Spain & $\begin{array}{l}\text { PSOE } \\
\text { Izquierda Unida } \\
\text { Podemos (and local variants) } \\
\text { ERC } \\
\text { ICV } \\
\text { Eusko Alkartasuna } \\
\text { Bloque Nacionalista Galego } \\
\text { Partido Andalucista } \\
\text { Chunta Argonesista } \\
\text { UPyD } \\
\text { Amaiur } \\
\text { Ciudadanos }\end{array}$ & $\begin{array}{l}2.86 \\
1.73 \\
1.75 \\
2.39 \\
2.01 \\
4.45 \\
2.46 \\
4.43 \\
1.94 \\
3.33 \\
2.14 \\
3.22\end{array}$ \\
\hline FI - Finland & $\begin{array}{l}\text { Svenka folkpariet } \\
\text { Vihreä Litto } \\
\text { Suomen Sosialdemokraattinen } \\
\text { Vasemmistoliitto }\end{array}$ & $\begin{array}{l}3.72 \\
2.18 \\
4.28 \\
3.25\end{array}$ \\
\hline FR - France & $\begin{array}{l}\text { Parti Communiste Français } \\
\text { Parti Socialiste } \\
\text { Les Verts } \\
\text { Parti Radical de Gauche } \\
\text { Front de Gauche }\end{array}$ & $\begin{array}{l}4.41 \\
3.06 \\
1.62 \\
3.78 \\
2.4\end{array}$ \\
\hline GB - United Kingdom & $\begin{array}{l}\text { Labour Party } \\
\text { Liberal Democrats } \\
\text { Green Party } \\
\text { Plaid Cymru } \\
\text { SNP }\end{array}$ & $\begin{array}{l}4.29 \\
2.60 \\
1.61 \\
3.78 \\
4.06\end{array}$ \\
\hline IE - Ireland & $\begin{array}{l}\text { Labour Party } \\
\text { Green Party } \\
\text { People Before profit } \\
\text { Progressive Democrats } \\
\text { Socialist Party }\end{array}$ & $\begin{array}{l}3.46 \\
2.18 \\
1.20 \\
3.89 \\
2.04\end{array}$ \\
\hline NL - Netherlands & $\begin{array}{l}\text { PvdA } \\
\text { Democraten '66 } \\
\text { GroenLinks } \\
\text { Socialiste Partij } \\
\text { 50PLUS } \\
\text { PvdD }\end{array}$ & $\begin{array}{l}3.52 \\
1.76 \\
1.74 \\
4.58 \\
4.33 \\
3.07\end{array}$ \\
\hline PT - Portugal & $\begin{array}{l}\text { Bloco de Esquerda } \\
\text { Coligação Democrática Unitária } \\
\text { (PCP/PEV) } \\
\text { Partido Socialista }\end{array}$ & $\begin{array}{l}1.06 \\
2.75 \\
3.19\end{array}$ \\
\hline SE - Sweden & $\begin{array}{l}\text { Arbetarparteit-Socialdemokraterna } \\
\text { Vänsterpartiet }\end{array}$ & $\begin{array}{l}4.48 \\
2.71\end{array}$ \\
\hline
\end{tabular}




\begin{tabular}{|l|l|l|}
\hline & Miljöpartiet de Gröna & 2.48 \\
& Folkpartiet liberalerna & 3.27 \\
& Feministiskt initiative & 0.81 \\
& Piratpartiet & 1.68 \\
\hline
\end{tabular}

Does not include data for Switzerland or Norway as these countries are not included in the CHES dataset.

Table A 11: Tough test regression models

\begin{tabular}{|c|c|c|c|c|}
\hline & \multicolumn{2}{|c|}{ Ideology } & \multicolumn{2}{|c|}{ Vote choice } \\
\hline & Main model & Tough test & Main model & Tough test \\
\hline \multirow[t]{2}{*}{ LGB } & $0.33 * *$ & $0.33 * *$ & $0.32 * * *$ & $0.32 * * *$ \\
\hline & $(0.14)$ & $(0.15)$ & $(0.06)$ & $(0.05)$ \\
\hline \multirow{2}{*}{ Gender (1 male) } & $-0.08^{*}$ & -0.06 & $-0.13 * * *$ & $-0.12 * * *$ \\
\hline & $(0.05)$ & $(0.05)$ & $(0.03)$ & $(0.03)$ \\
\hline \multirow{2}{*}{ Age } & -0.00 & 0.00 & -0.00 & -0.00 \\
\hline & $(0.00)$ & $(0.00)$ & $(0.00)$ & $(0.00)$ \\
\hline \multicolumn{5}{|c|}{ Education (base: primary) } \\
\hline \multirow[t]{2}{*}{ Low secondary } & -0.08 & -0.09 & $-0.19 *$ & $-0.19 *$ \\
\hline & $(0.09)$ & $(0.08)$ & $(0.11)$ & $(0.11)$ \\
\hline \multirow[t]{2}{*}{ High secondary } & -0.06 & -0.06 & $-0.32 * * *$ & $-0.32 * *$ \\
\hline & $(0.08)$ & $(0.08)$ & $(0.11)$ & $(0.13)$ \\
\hline \multirow[t]{2}{*}{ Post-secondary } & $0.20 * * *$ & $0.19 * * *$ & -0.14 & -0.15 \\
\hline & $(0.07)$ & $(0.07)$ & $(0.15)$ & $(0.16)$ \\
\hline \multirow[t]{2}{*}{ Higher education } & $0.40 * * *$ & $0.41 * * *$ & -0.14 & -0.15 \\
\hline & $(0.08)$ & $(0.07)$ & $(0.13)$ & $(0.15)$ \\
\hline \multirow[t]{2}{*}{ Income } & -0.01 & -0.01 & $-0.04 * * *$ & $-0.04 * * *$ \\
\hline & $(0.01)$ & $(0.01)$ & $(0.01)$ & $(0.01)$ \\
\hline \multirow[t]{2}{*}{ Religiosity } & $-0.11 * * *$ & $-0.11 * * *$ & $-0.09 * * *$ & $-0.09 * * *$ \\
\hline & $(0.01)$ & $(0.01)$ & $(0.02)$ & $(0.02)$ \\
\hline \multicolumn{5}{|c|}{ Domicile (base: City/urban) } \\
\hline \multirow[t]{2}{*}{ City suburbs } & $-0.19 * * *$ & $-0.20 * * *$ & $-0.15 * * *$ & $-0.14 * * *$ \\
\hline & $(0.03)$ & $(0.03)$ & $(0.05)$ & $(0.05)$ \\
\hline \multirow[t]{2}{*}{ Town/small city } & $-0.26 * * *$ & $-0.26 * * *$ & $-0.29 * * *$ & $-0.28 * * *$ \\
\hline & $(0.05)$ & $(0.05)$ & $(0.09)$ & $(0.10)$ \\
\hline \multirow[t]{2}{*}{ Village } & $-0.38 * * *$ & $-0.39 * * *$ & $-0.51 * * *$ & $-0.50 * * *$ \\
\hline & $(0.07)$ & $(0.06)$ & $(0.10)$ & $(0.11)$ \\
\hline \multirow[t]{2}{*}{ Country/farm } & $-0.54 * * *$ & $-0.54 * * *$ & $-0.87 * * *$ & $-0.83 * * *$ \\
\hline & $(0.05)$ & $(0.05)$ & $(0.22)$ & $(0.22)$ \\
\hline \multirow[t]{2}{*}{ View of economy } & $-0.04 * * *$ & $-0.04 * * *$ & -0.02 & -0.02 \\
\hline & $(0.01)$ & $(0.01)$ & $(0.02)$ & $(0.02)$ \\
\hline \multirow[t]{2}{*}{ Sat. with democracy } & 0.00 & -0.00 & $0.03 * * *$ & $0.03 * *$ \\
\hline & $(0.01)$ & $(0.01)$ & $(0.01)$ & $(0.01)$ \\
\hline Country effects & $\checkmark$ & $\checkmark$ & $\checkmark$ & $\checkmark$ \\
\hline Year effects & $\checkmark$ & $\checkmark$ & $\checkmark$ & $\checkmark$ \\
\hline \multirow[t]{2}{*}{ Constant } & 0.06 & 0.02 & $0.70 * *$ & $0.62 *$ \\
\hline & $(0.09)$ & $(0.11)$ & $(0.33)$ & $(0.36)$ \\
\hline Observations & 90,747 & 82,668 & 73,601 & 67,573 \\
\hline
\end{tabular}

Robust country clustered standard errors (two-tailed) in parentheses 
$* * * \mathrm{p}<0.01, * * \mathrm{p}<0.05, * \mathrm{p}<0.1$

Table A 12: Modelling LGB vote for liberal (GAL-TAN) parties

\begin{tabular}{|c|c|c|c|c|}
\hline & \multicolumn{2}{|c|}{$(1)$} & \multicolumn{2}{|c|}{ (2) } \\
\hline & Coef. & AME & Coef. & AME \\
\hline LGB & $\begin{array}{c}0.34 * * * \\
(0.07)\end{array}$ & $\begin{array}{c}7.81 * * * \\
(1.60)\end{array}$ & $\begin{array}{c}0.31 * * * \\
(0.07)\end{array}$ & $\begin{array}{c}7.08 * * * \\
(1.64)\end{array}$ \\
\hline Gender (1 male) & $\begin{array}{c}-0.05^{* *} \\
(0.02)\end{array}$ & $\begin{array}{c}-1.14^{* *} \\
(0.53)\end{array}$ & $\begin{array}{c}-0.13 * * * \\
(0.02)\end{array}$ & $\begin{array}{c}-2.92 * * * \\
(0.52)\end{array}$ \\
\hline Age & $\begin{array}{c}0.01 * * * \\
(0.00)\end{array}$ & $\begin{array}{c}0.24 * * * \\
(0.06)\end{array}$ & $\begin{array}{c}0.01 * * * \\
(0.00)\end{array}$ & $\begin{array}{c}0.29 * * * \\
(0.05)\end{array}$ \\
\hline \multicolumn{5}{|c|}{ Education (base: primary) } \\
\hline Low secondary & $\begin{array}{l}-0.02 \\
(0.10)\end{array}$ & $\begin{array}{l}-0.36 \\
(2.17)\end{array}$ & $\begin{array}{l}-0.05 \\
(0.09)\end{array}$ & $\begin{array}{l}-1.17 \\
(1.89)\end{array}$ \\
\hline High secondary & $\begin{array}{c}0.07 \\
(0.08)\end{array}$ & $\begin{array}{l}1.53 \\
(1.78)\end{array}$ & $\begin{array}{c}0.02 \\
(0.08)\end{array}$ & $\begin{array}{c}0.39 \\
(1.70)\end{array}$ \\
\hline Post-secondary & $\begin{array}{c}0.33 * * * \\
(0.12)\end{array}$ & $\begin{array}{c}7.50 * * * \\
(2.74)\end{array}$ & $\begin{array}{c}0.28 * * \\
(0.11)\end{array}$ & $\begin{array}{c}6.40 * * \\
(2.51)\end{array}$ \\
\hline Higher education & $\begin{array}{c}0.38 * * * \\
(0.09)\end{array}$ & $\begin{array}{c}8.84 * * * \\
(1.96)\end{array}$ & $\begin{array}{c}0.32 * * * \\
(0.09)\end{array}$ & $\begin{array}{c}7.33 * * * \\
(2.03)\end{array}$ \\
\hline Income & $\begin{array}{c}0.03 * * * \\
(0.01)\end{array}$ & $\begin{array}{c}0.76^{* * * *} \\
(0.23)\end{array}$ & $\begin{array}{c}0.03 * * \\
(0.01)\end{array}$ & $\begin{array}{c}0.58 * * \\
(0.29)\end{array}$ \\
\hline Religiosity & & & $\begin{array}{c}-0.08 * * * \\
(0.02)\end{array}$ & $\begin{array}{c}-1.90 * * * \\
(0.37)\end{array}$ \\
\hline \multicolumn{5}{|c|}{ Domicile (base: City/urban) } \\
\hline City suburbs & & & $\begin{array}{l}-0.08 \\
(0.05)\end{array}$ & $\begin{array}{l}-1.83 \\
(1.27)\end{array}$ \\
\hline Town/small city & & & $\begin{array}{c}-0.18^{* *} \\
(0.08)\end{array}$ & $\begin{array}{c}-4.10^{* *} \\
(1.88)\end{array}$ \\
\hline Village & & & $\begin{array}{c}-0.27 * * * \\
(0.08)\end{array}$ & $\begin{array}{c}-6.26 * * * \\
(1.88)\end{array}$ \\
\hline Country/farm & & & $\begin{array}{c}-0.55^{* * * *} \\
(0.14)\end{array}$ & $\begin{array}{c}-12.18 * * * \\
(2.95)\end{array}$ \\
\hline View of economy & & & $\begin{array}{r}-0.02^{*} \\
(0.01)\end{array}$ & $\begin{array}{l}-0.48^{*} \\
(0.29)\end{array}$ \\
\hline Sat. with democracy & & & $\begin{array}{c}0.03 * * * \\
(0.01)\end{array}$ & $\begin{array}{c}0.77 * * * \\
(0.16)\end{array}$ \\
\hline Country effects & \multicolumn{2}{|c|}{$\checkmark$} & \multicolumn{2}{|c|}{$\checkmark$} \\
\hline Year effects & \multicolumn{2}{|c|}{$\checkmark$} & \multicolumn{2}{|c|}{$\checkmark$} \\
\hline Constant & \multicolumn{2}{|c|}{$\begin{array}{c}-1.09 * * * \\
(0.23)\end{array}$} & \multicolumn{2}{|c|}{$\begin{array}{c}-0.53 * * * \\
(0.19)\end{array}$} \\
\hline Observations & \multicolumn{2}{|c|}{78,706} & \multicolumn{2}{|c|}{76,684} \\
\hline
\end{tabular}

Robust country clustered standard errors (two-tailed) in parentheses $* * * \mathrm{p}<0.01, * * \mathrm{p}<0.05, * \mathrm{p}<0.1$ 
Table A 13: Effects comparison

\begin{tabular}{ll}
\hline Effect & Logit coefficient (including controls) \\
\hline Effect on vote (Europe) & $0.32^{* * *}$ (Present study) \\
Effect on vote in (US Presidential) & $0.12^{\dagger}$ (Egan 2012) - "Self-selection adj. estimate" \\
Effect on vote (US Presidential) & $0.23^{\dagger}$ (Egan 2012) - "Naïve estimate" \\
Effect on vote (US House) & $0.69^{* * *}$ (Hertzog 1996) \\
Effect on vote (US Senate) & $0.34^{\dagger}$ (Hertzog 1996) \\
Effect on vote (US Gubernatorial) & $0.47^{*}$ (Hertzog 1996) \\
Effect on vote (US Presidential) & $1.40^{* * *}$ (Hertzog 1996) \\
$* * * \mathrm{p}<0.01, * * \mathrm{p}<0.05, * \mathrm{p}<0.1,{ }^{\dagger} p>0.1$ &
\end{tabular}

Table A 14: Variation in fixed effects controls

\begin{tabular}{|c|c|c|c|c|}
\hline & \multicolumn{2}{|c|}{ Ideology } & \multicolumn{2}{|c|}{ Vote choice } \\
\hline & $\begin{array}{c}\text { Country \& Year } \\
\text { FE }\end{array}$ & $\begin{array}{c}\text { Election } \\
\text { FE }\end{array}$ & $\begin{array}{c}\text { Country \& Year } \\
\text { FE }\end{array}$ & $\begin{array}{c}\text { Election } \\
\text { FE }\end{array}$ \\
\hline LGB & $\begin{array}{l}0.33 * * \\
(0.14)\end{array}$ & $\begin{array}{l}0.33 * * \\
(0.14)\end{array}$ & $\begin{array}{c}0.34 * * * \\
(0.07)\end{array}$ & $\begin{array}{c}0.34 * * * \\
(0.07)\end{array}$ \\
\hline Gender (1 male) & $\begin{array}{l}-0.08^{*} \\
(0.05)\end{array}$ & $\begin{array}{l}-0.08 \\
(0.05)\end{array}$ & $\begin{array}{c}-0.13 * * * \\
(0.03)\end{array}$ & $\begin{array}{c}-0.14 * * * \\
(0.03)\end{array}$ \\
\hline Age & $\begin{array}{l}-0.00 \\
(0.00)\end{array}$ & $\begin{array}{l}-0.00 \\
(0.00)\end{array}$ & $\begin{array}{l}-0.00 \\
(0.00)\end{array}$ & $\begin{array}{l}-0.00 \\
(0.00)\end{array}$ \\
\hline $\begin{array}{l}\text { Education (base: } \\
\text { primary) }\end{array}$ & & & & \\
\hline Low secondary & $\begin{array}{l}-0.08 \\
(0.09)\end{array}$ & $\begin{array}{l}-0.08 \\
(0.09)\end{array}$ & $\begin{array}{l}-0.20^{*} \\
(0.11)\end{array}$ & $\begin{array}{l}-0.19^{*} \\
(0.11)\end{array}$ \\
\hline High secondary & $\begin{array}{l}-0.06 \\
(0.08)\end{array}$ & $\begin{array}{l}-0.05 \\
(0.07)\end{array}$ & $\begin{array}{c}-0.33 * * * \\
(0.12)\end{array}$ & $\begin{array}{c}-0.30 * * * \\
(0.11)\end{array}$ \\
\hline Post-secondary & $\begin{array}{c}0.20 * * * \\
(0.07)\end{array}$ & $\begin{array}{c}0.20 * * * \\
(0.07)\end{array}$ & $\begin{array}{l}-0.15 \\
(0.15)\end{array}$ & $\begin{array}{l}-0.11 \\
(0.14)\end{array}$ \\
\hline Higher education & $\begin{array}{c}0.40 * * * \\
(0.08)\end{array}$ & $\begin{array}{c}0.41 * * * \\
(0.07)\end{array}$ & $\begin{array}{l}-0.15 \\
(0.14)\end{array}$ & $\begin{array}{l}-0.12 \\
(0.14)\end{array}$ \\
\hline Income & $\begin{array}{l}-0.01 \\
(0.01)\end{array}$ & $\begin{array}{l}-0.01 \\
(0.01)\end{array}$ & $\begin{array}{c}-0.04 * * * \\
(0.01)\end{array}$ & $\begin{array}{c}-0.05 * * * \\
(0.02)\end{array}$ \\
\hline Religiosity & $\begin{array}{c}-0.11 * * * \\
(0.01)\end{array}$ & $\begin{array}{c}-0.11 * * * \\
(0.01)\end{array}$ & $\begin{array}{c}-0.10 * * * \\
(0.02)\end{array}$ & $\begin{array}{c}-0.10 * * * \\
(0.02)\end{array}$ \\
\hline $\begin{array}{l}\text { Domicile (base: } \\
\text { City/urban) }\end{array}$ & & & & \\
\hline City suburbs & $\begin{array}{c}-0.19 * * * \\
(0.03)\end{array}$ & $\begin{array}{c}-0.19 * * * \\
(0.03)\end{array}$ & $\begin{array}{c}-0.16^{* * *} \\
(0.04)\end{array}$ & $\begin{array}{c}-0.17 * * * \\
(0.05)\end{array}$ \\
\hline Town/small city & $\begin{array}{c}-0.26 * * * \\
(0.05)\end{array}$ & $\begin{array}{c}-0.26 * * * \\
(0.05)\end{array}$ & $\begin{array}{c}-0.30 * * * \\
(0.09)\end{array}$ & $\begin{array}{c}-0.30 * * * \\
(0.09)\end{array}$ \\
\hline Village & $\begin{array}{c}-0.38 * * * \\
(0.07)\end{array}$ & $\begin{array}{c}-0.39 * * * \\
(0.07)\end{array}$ & $\begin{array}{c}-0.50 * * * \\
(0.10)\end{array}$ & $\begin{array}{c}-0.51^{* * *} \\
(0.10)\end{array}$ \\
\hline Country/farm & $\begin{array}{c}-0.54 * * * \\
(0.05)\end{array}$ & $\begin{array}{c}-0.55 * * * \\
(0.05)\end{array}$ & $\begin{array}{c}-0.88 * * * \\
(0.22)\end{array}$ & $\begin{array}{c}-0.89 * * * \\
(0.22)\end{array}$ \\
\hline
\end{tabular}




\begin{tabular}{lcccc} 
View of economy & $-0.04 * * *$ & $-0.05^{* * *}$ & -0.02 & $-0.03^{* * *}$ \\
& $(0.01)$ & $(0.01)$ & $(0.01)$ & $(0.01)$ \\
Sat. with democracy & 0.00 & 0.00 & $0.03^{* *}$ & $0.03^{* * *}$ \\
& $(0.01)$ & $(0.01)$ & $(0.01)$ & $(0.01)$ \\
Country effects & $\checkmark$ & $X$ & $\checkmark$ & $X$ \\
Year effects & $\checkmark$ & $X$ & $\checkmark$ & $X$ \\
Election effects & $X$ & $\checkmark$ & $X$ & $\checkmark$ \\
Constant & 0.06 & $0.16^{* * *}$ & $0.72^{* *}$ & $0.75^{* * *}$ \\
& $(0.09)$ & $(0.06)$ & $(0.32)$ & $(0.25)$ \\
Observations & & & & 73,601 \\
\hline
\end{tabular}

Robust country-clustered standard errors (two-tailed) in parentheses $* * * \mathrm{p}<0.01,{ }^{*} \mathrm{p}<0.05,{ }^{*} \mathrm{p}<0.1$

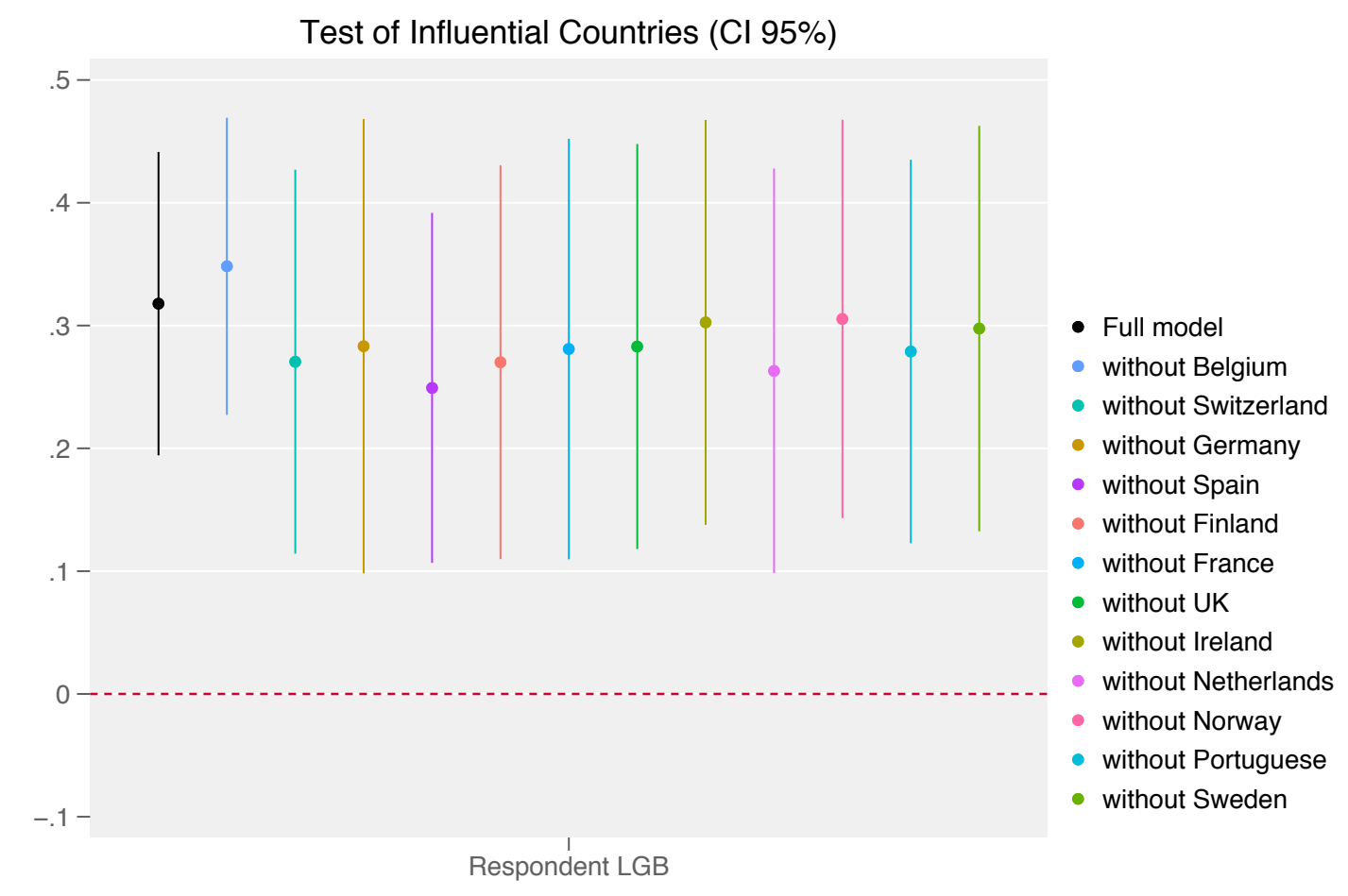

Figure A 1: Country-based sensitivity test 
Tes of Influential Survey Years

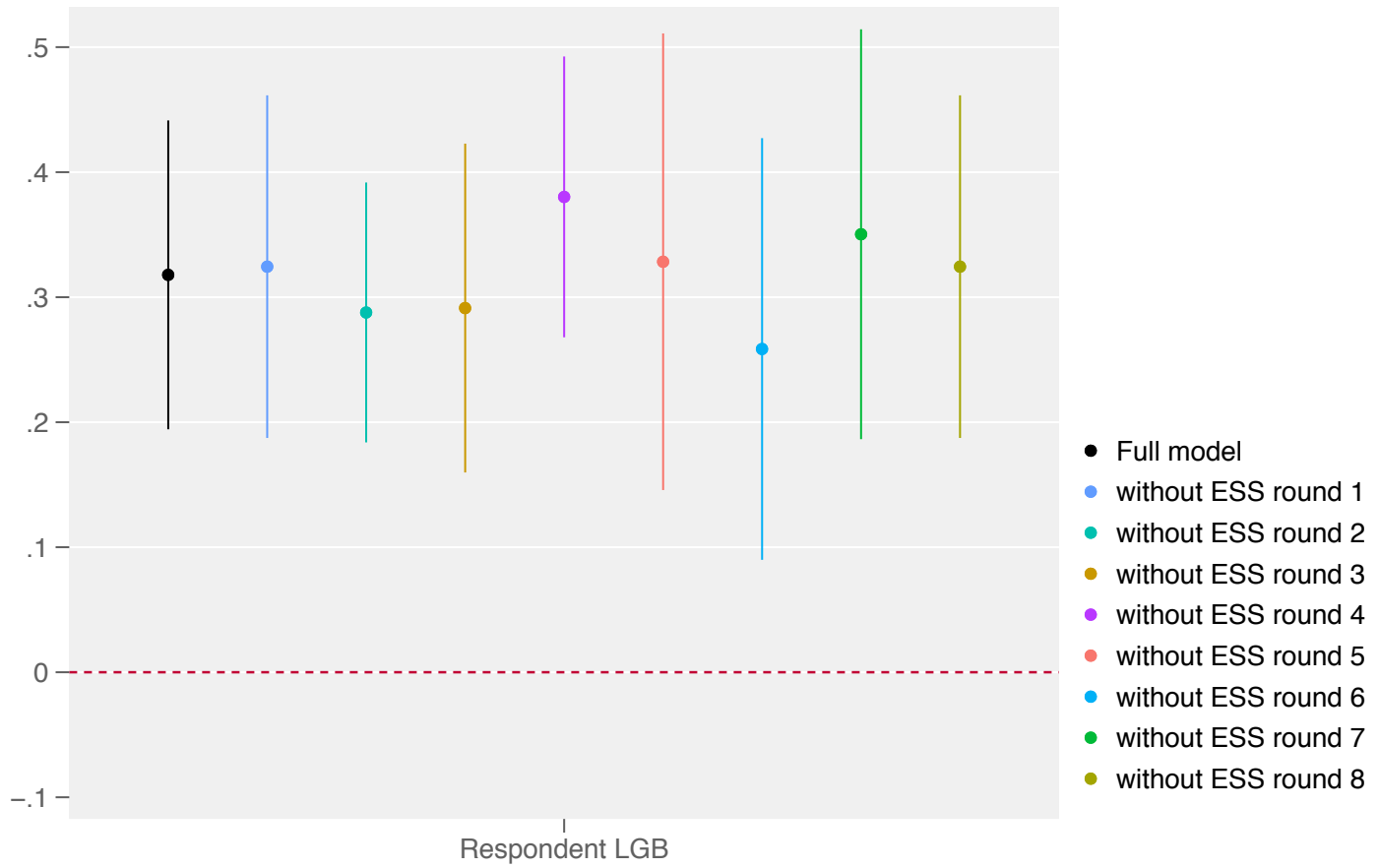

Figure A 2: Survey-based sensitivity test 